\title{
Heavy halogen geochemistry of martian shergottite meteorites and implications for the halogen composition of the depleted shergottite mantle source
}

\author{
Patricia L. Clay ${ }^{1, *, \S, ~ K a t h e r i n e ~ H . ~ J o y ~}{ }^{1}$, Brian O’Driscoll ${ }^{1}$, Henner BusemanN ${ }^{2}, \|$, \\ LORRAINE RUZIÉ-HAMILTON ${ }^{1}$, RAY BURGESS ${ }^{1} \uparrow$, JONATHAN FELlOWES ${ }^{1}$, BASTIAN JOACHIM-MROSKO ${ }^{3}$,

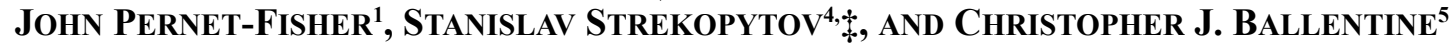

\author{
${ }^{1}$ Department of Earth and Environmental Sciences, University of Manchester, Manchester, M13 9PL, U.K. \\ ${ }^{2}$ Institute for Geochemistry and Petrology, ETH Zürich, Clausiusstrasse 25, 8092 Zürich, Switzerland \\ ${ }^{3}$ Institute of Mineralogy and Petrography, University of Innsbruck, Innrain 52f, A-6020 Innsbruck, Austria \\ ${ }^{4}$ Imaging and Analysis Centre, Natural History Museum, Cromwell Road, London, SW7 5BD, U.K. \\ ${ }^{5}$ Department of Earth Sciences, University of Oxford, South Parks Road, Oxford, OX1 3AN, U.K.
}

\begin{abstract}
Volatile elements (e.g., H, C, N) have a strong influence on the physical and chemical evolution of planets and are essential for the development of habitable conditions. Measurement of the volatile and incompatible heavy halogens, $\mathrm{Cl}, \mathrm{Br}$, and $\mathrm{I}$, can provide insight into volatile distribution and transport processes, due to their hydrophilic nature. However, information on the bulk halogen composition of martian meteorites is limited, particularly for $\mathrm{Br}$ and I, largely due to the difficulty in measuring ppblevel $\mathrm{Br}$ and I abundances in small samples. In this study, we address this challenge by using the neutron irradiation noble gas mass spectrometry (NI-NGMS) method to measure the heavy halogen composition of five olivine-phyric shergottite meteorites, including the enriched (Larkman Nunatak LAR 06319 and LAR 12011) and depleted (LAR 12095, LAR 12240, and Tissint) compositional end-members. Distinct differences in the absolute abundances and halogen ratios exist between enriched (74 to136 ppm Cl, 1303 to $3061 \mathrm{ppb} \mathrm{Br}$, and 4 to $1423 \mathrm{ppb}$ I) and depleted (10 to $26 \mathrm{ppm} \mathrm{Cl}, 46$ to $136 \mathrm{ppb} \mathrm{Br}$, and 3 to $329 \mathrm{ppb}$ I) samples. All halogen measurements are within the ranges previously reported for martian shergottite, nakhlite, and chassignite (SNC) meteorites. Enriched shergottites show variable and generally high $\mathrm{Br}$ and $\mathrm{I}$ absolute abundances. Halogen ratios $(\mathrm{Br} / \mathrm{Cl}$ and $\mathrm{I} / \mathrm{Cl})$ are in proportions that exceed those of both carbonaceous chondrites and the martian surface. This may be linked to a volatile-rich martian mantle source, be related to shock processes or could represent a small degree of heavy halogen contamination (a feature of some Antarctic meteorites, for example). The differences observed in halogen abundances and ratios between enriched and depleted compositions, however, are consistent with previous suggestions of a heterogeneous distribution of volatiles in the martian mantle. Depleted shergottites have lower halogen abundances and $\mathrm{Br}$ and $\mathrm{Cl}$ in similar proportions to bulk silicate Earth and carbonaceous chondrites. Tissint in particular, as an uncontaminated fall, allows an estimate of the depleted shergottite mantle source composition to be made: $1.2 \mathrm{ppm} \mathrm{Cl}, 7.0 \mathrm{ppb} \mathrm{Br}$, and $0.2 \mathrm{ppb}$ I. The resultant bulk silicate Mars (BSM) estimate (22 ppm Cl, $74 \mathrm{ppb} \mathrm{Br}$, and $6 \mathrm{ppb} \mathrm{I),}$ including the martian crust and depleted shergottite mantle, is similar to estimates of the bulk silicate earth (BSE) halogen composition.
\end{abstract}

Keywords: Mars, shergottites, meteorites, halogens, noble gas, volatile, geochemistry, planetary habitability; Halogens in Planetary Systems

\section{INTRODUCTION}

Volatile elements (e.g., H, C, N) are essential to life on Earth. Dissolved salts, such as chlorides, perchlorates, and sulfates, that are present in aqueous fluids impact the physical (e.g., freezing point) and chemical (e.g., $\mathrm{pH}$ ) properties of these fluids and

\footnotetext{
*E-mail: patricia.clay@manchester.ac.uk. Orcid 0000-0002-6175-9761.

+ Orcid 0000-0001-7674-8718

|| Orcid 0000-0002-0867-6908.

+ Present address: National Measurement Laboratory, LGC Ltd, Queens Road, Teddington, TW11 0LY, U.K.

$\S$ Special collection papers can be found online at http://www.minsocam.org/MSA/

AmMin/special-collections.html.
}

therefore the ability of surface or subsurface liquid environments to host life. The heavy halogens $(\mathrm{Cl}, \mathrm{Br}$, and $\mathrm{I})$ are important components of salts in aqueous fluids, such as recently described for subsurface cold brine environments (Orosei et al. 2018; Stamenković et al. 2018) on Mars. Therefore, characterizing the origin and distribution of the halogens in the terrestrial planets is important for a better understanding of planetary habitability.

The heavy halogens are highly incompatible and volatile elements, indicating that their general distribution should be influenced by partial melting processes, magmatic fractionation, and degassing (Aiuppa et al. 2009). Their hydrophilic behavior means that they are mobilized by, and track with, aqueous fluids. 
Coupled with their typically low abundances in most geologic materials, these factors make the halogens excellent tracers of volatile evolution and transport processes in terrestrial planets.

Currently, there are three sources of information on the volatile budget of the martian surface and interior: (1) martian meteorites (Cartwright et al. 2013; Filiberto et al. 2016a; McCubbin et al. 2016), (2) orbital measurements (e.g., Mars Odyssey Gamma Ray Spectrometer; Keller et al. 2006), and (3) in situ measurements made by landers (e.g., Viking and Phoenix; Baird et al. 1976) and rovers (e.g., Curiosity, Opportunity and Spirit; Gellert et al. 2004, 2006). Martian meteorites currently offer the only direct source of information on the volatile composition of the martian mantle. The volcanic nature of these samples means they also offer the opportunity to understand volatile transfer processes between the martian mantle and crust. This may provide insight into a planet where plate tectonic activity, a critical process for volatile transport and recycling through subduction zones on Earth (Holland and Ballentine 2006), is not thought to have operated. Potential fluid-rock interaction on the surface of Mars may also be recorded in these samples, in the form of alteration products preserved in meteorite samples, though this can be difficult to categorically distinguish from terrestrial alteration of these materials. Bulk rock halogen studies on martian meteorites suggest that Mars is relatively volatile-rich (Dreibus and Wänke 1985), and in situ measurements of $\mathrm{Cl}$ and $\mathrm{Br}$ on the martian surface suggest a halogen-rich crust (e.g., Gellert et al. 2006), likely due to the presence of alteration mineral assemblages. However, measurements of $\mathrm{OH}$ and halogens in martian apatite and amphibole hosted within volcanic samples are highly variable (Filiberto et al. 2016a, 2016b; McCubbin et al. 2016), indicating that martian mantle volatiles are heterogeneously distributed and that Mars' mantle is similar to, or drier than, currently accepted estimates of terrestrial mantle sources (e.g., Saal et al. 2002).

There are currently only limited bulk heavy halogen measurements available for martian meteorite samples. This is particularly true for $\mathrm{Br}$ and I. In this study, we use the neutron irradiation noble gas mass spectrometry (NI-NGMS; RuziéHamilton et al. 2016) method to measure the heavy halogen $(\mathrm{Cl}$, $\mathrm{Br}$, and I) abundances and ratios of five shergottite meteorites. Our aim is to characterize the halogen composition of the depleted and enriched shergottite mantle source(s) and thus better constrain the halogen abundance of the martian interior.

By evaluating these measurements in the context of what is known about the abundances of the halogens in the martian crust, we are able to shed light on the halogen budget of the martian mantle. Furthermore, this allows volatile transport mechanisms to be investigated, with broader implications for the role that such fluids play in creating potentially habitable environments.

\section{SAMPLE DESCRIPTIONS}

Martian meteorites comprise shergottites, nakhlites, and chassingites, collectively known as the SNC's (Bridges and Warren 2006), as well as the orthopyroxenite Allan Hills (ALHA) 84001 and the grouped "Black Beauty" breccia samples (e.g., Northwest Africa NWA 7034 and paired stones). Due to the noncumulate volcanic nature of many of the shergottite meteorites, they can provide constraints on the volatile source composition of the mantle from which they are derived. Shergottites are generally subdivided based on their chondritic-relative rare earth element (REE) geochemistry, into "enriched" and "depleted" compositions (Herd et al. 2002; Borg and Draper 2003). The latter compositional variations have been interpreted to reflect different geochemical reservoirs on Mars (e.g., Symes et al. 2008), or alternatively, varying degrees of crustal contamination and assimilation (e.g., Herd et al. 2002). Recently, enriched and depleted shergottites have been interpreted as representing the products of partial melting of chemically distinct, deep mantle sources (Day et al. 2018) whose reservoirs formed as early as $\sim 4504$ Ma (e.g., Borg et al. 2016). Shergottite crystallization ages fall into three distinct groups: $\sim 180, \sim 340$, and $>474 \mathrm{Ma}$ (Symes et al. 2008; Shafer et al. 2010) with ejection ages that vary from $1.1 \pm 0.2 \mathrm{Ma}$ (depleted) to $\sim 1-5 \mathrm{Ma}$ (intermediate and enriched) (Lapen et al. 2017). One notable exception is the augite-rich shergottite, NWA 8159, which has a crystallization age of $2.37 \pm 0.25 \mathrm{Ga}$ (Herd et al. 2017).

The shergottite group contains a range of textural associations, ranging from poikilitic lherzolites (plagioclase-poor), olivine-phyric, and aphyric (commonly referred to as basaltic) (Goodrich 2002). There is debate over the origin of the olivinephyric shergottite subgroup, with some favoring an origin by mixing of basaltic and lherzolitic shergottite end-members (e.g., Mittlefehldt et al. 1999) and others suggesting that the olivine is re-entrained cumulate (e.g., Usui et al. 2008). In this study, five olivine-phyric shergottite meteorites, including the hot desert fall Tissint and four Antarctic find meteorites from the Larkman Nunatak (LAR) icefield (paired stones LAR 06319/12011 and paired stones LAR 12095/12240), are studied. The samples represent both enriched and depleted shergottite compositions. Sample descriptions are summarized below and in Table 1.

\section{Tissint}

The Tissint meteorite fell on July 18, 2011, in Morocco (Chennaoui Aoudjehane et al. 2012). As only the fifth observed fall of a martian meteorite, Tissint presents the opportunity to gain insight into the composition of the martian interior and also the products of martian surface alteration, due to short terrestrial residence time and consequent lack of terrestrial alteration (though evidence of fluid-mineral reaction on Mars' surface is preserved in Tissint; Steele et al. 2018). Tissint is classified as a depleted, olivine-phyric shergottite, based on its bulk and trace element composition (Irving et al. 2012; Chennaoui Aoudjehane et al. 2012), within the range reported for basaltic shergottites. Groundmass and glass-rich samples of Tissint, however, have shown a LREE-enriched component similar to enriched shergottites (Chennaoui Aoudjehane et al. 2012).

Tissint contains large $(\leq 2 \mathrm{~mm})$ crystals of porphyritic olivine in a fine-grained groundmass of olivine (25-28 vol\%), maskelynite (a shock-related, high-pressure plagioclase pseudomorph; 20-22 vol\%), orthopyroxene and clinopyroxene (50-52 vol\%), and minor phases including oxides (1-2 vol\%), sulfides, and phosphates (Balta et al. 2015b). Oxide phases encompass a full compositional range from chromite to ulvöspinel (Balta et al. 2015b). The main sulfide is pyrrhotite. Phosphates are dominantly merrillite, though rare apatite has been documented (Chennaoui Aoudjehane et al. 2012). A crystallization 
TABLE 1. Summary of sample information for Tissint, and pairs LAR 06319/12011 and LAR 12095/12240

\begin{tabular}{|c|c|c|c|c|c|}
\hline Sample & Type & REE classification & Modal mineralogy (vol\%) & Crystallization age (Ma) & CRE age $(\mathrm{Ma})$ \\
\hline Tissint & Olivine-phyric shergottite & Depleted & $\begin{array}{c}25-28 \% \text { olivine } \\
50-52 \% \text { pyroxene } \\
25-28 \% \text { maskelynite } \\
1-2 \% \text { phosphates, oxides } \\
\text { and sulfides [1] }\end{array}$ & $574 \pm 20[4]$ & $0.7 \pm 0.3[5]$ \\
\hline LAR 12095/12240 & Olivine-phyric shergottite & Depleted & $\begin{array}{c}16-17 \% \text { olivine } \\
61-62 \% \text { pyroxene } \\
21-22 \% \text { as maskelynite } \\
1 \% \text { phosphates, oxides, } \\
\text { and sulfides [2] }\end{array}$ & $\begin{array}{c}\text { NA } \\
\sim 400-550 \text { Ma estimate [6] }\end{array}$ & $0.84 \pm 0.15$ (this work) \\
\hline LAR 12011/06139 & Olivine-phyric shergottite & Enriched & $\begin{array}{c}\sim 24 \% \text { olivine } \\
54 \% \text { pyroxene } \\
\sim 18 \% \text { maskelynite } \\
2.1 \% \text { phosphates, } 1.3 \% \text { oxides } \\
\text { and } 0.3 \% \text { sulfides [3] }\end{array}$ & $163 \pm 13$ to $207 \pm 14 \mathrm{Ma}$ [7-9] & $\begin{array}{c}2.4-3.3[7,10] \\
0.35 \pm 0.05 \text { (this work) }\end{array}$ \\
\hline
\end{tabular}

Notes: References: [1] Balta et al. 2015b; [2] Dunham et al. 2019; [3] Basu Sarbadhikari et al. (2009); [4] Brennecka et al. (2014); [5] Chennaoui Aoudjehane et al. (2012); [6] Righter et al. (2015); [7] Park et al. (2013); [8] Shih et al. (2009); [9] Shafer et al. (2010); [10] Nagao and Park (2008).

age of $574 \pm 20 \mathrm{Ma}$ has been reported for Tissint (Brennecka et al. 2014), with initial ${ }^{87} \mathrm{Sr} /{ }^{86} \mathrm{Sr}$ and ${ }^{143} \mathrm{Nd} /{ }^{144} \mathrm{Nd}$ compositions distinct from all other martian meteorites, purportedly as a result of its derivation from an incompatible-element depleted mantle source (Brennecka et al. 2014). An ejection age of $0.7 \pm 0.3 \mathrm{Ma}$ was determined by Chennaoui Aoudjehane et al. (2012). Tissint has been suggested to have formed from closed-system fractional crystallization, representing a previously unsampled member of the shergottite group (Brennecka et al. 2014; Balta et al. 2015b).

The majority of martian meteorites are collected as unobserved finds from either hot desert (e.g., Northwest Africa "NWA," etc.) or cold desert environments (e.g., Antarctica). These environments may affect the primary halogen signature, either through leaching of halogens during terrestrial weathering (Clay et al. 2017) or deposition of halogens, particularly Cl and I, from sea spray and methyl iodide contaminants (Langenauer and Krähenbühl 1993). Tissint in particular, as an observed shergottite fall, therefore offers an excellent opportunity to investigate the primary halogen budget of the depleted shergottite mantle source.

\section{LAR 06319 and LAR 12011}

LAR 06139 was recovered from the Larkman Nunataks region of the Transantarctic Mountains, East Antarctica, in 2006 (McBride et al. 2007) and LAR 12011 was recovered in 2012 (McBride et al. 2013). LAR 06139, and to a lesser extent LAR 12011 , have been described in detail by previous workers (Basu Sarbadhikari et al. 2009, 2011, 2016; Peslier et al. 2010; Balta et al. 2013, 2015a; Howarth et al. 2016). Initial characterization of the stones suggested pairing, and this was supported by Balta et al. (2015a) on the basis of identical mineralogical and geochemical characteristics. The samples are olivine-pyhric shergottites that contain macrocrysts of olivine up to $3 \mathrm{~mm}$ in size (Shafer et al. 2010). The matrix consists of olivine (24.4 vol\%), pyroxene (54 vol\%), and maskelynite (17.8 vol\%) with minor phosphate ( $2.1 \mathrm{vol} \%)$, oxide $(1.3 \mathrm{vol} \%)$, and sulfide $(0.3 \mathrm{vol} \%)$ (Basu Sarbadhikari et al. 2009). Melt (glass) pockets and shock veins are also observed. Both olivine and pyroxene are compositionally zoned and contain abundant melt inclusions (Basu Sarbadhikari et al. 2009). Brown olivine in LAR 06319 is suggested to have formed during shock metamorphism under high $P$ - $T$ conditions of 30-55 GPa (Takenouchi et al. 2018). A lack of high-pressure phases is attributed to high post-shock temperatures (Fritz et al.
2005). The oxides include chromite to Ti-chromite, and phosphates are apatite, whitlockite, and merrillite. The dominantly OH-rich apatites in LAR 06139/12011 contain variable abundances of the halogens (Balta et al. 2013; Bellucci et al. 2017). LAR 06139/12011 have an "enriched" LREE signature typical of other basaltic shergottites (Basu Sarbadhikari et al. 2009; Brandon et al. 2012), relative to the depleted olivine-phyric lherzolitic shergottites. The crystallization ages from Ar-Ar (163 $\pm 13 \mathrm{Ma}$; Park et al. 2013), Rb-Sr (207 $\pm 14 \mathrm{Ma}$; Shih et al. 2009), Sm-Nd (190 \pm 29 Ma; Shih et al. 2009; $183 \pm 12$ Ma; Shafer et al. 2010), and Lu-Hf (179 $\pm 29 \mathrm{Ma}$; Shafer et al. 2010) dating for LAR 06139 are generally in good agreement. LAR 06139 (and therefore LAR 12011) is interpreted to be the product of partial melting of an incompatible element-enriched, oxidized martian mantle (Basu Sarbadhikari et al. 2009).

\section{LAR 12095 and LAR 12240}

LAR 12095 and LAR 12240 were recovered from the Larkman Nunataks region of the Transantarctic Mountains, East Antarctica in 2012 (McBride et al. 2013). They have been described in detail by several previous workers (Howarth et al. 2014; Mikouchi and Takenouchi 2014; Balta et al. 2015a; Funk et al. 2015; Funk 2016; Dunham et al. 2019) suggesting that on the basis of petrography, mineral-chemistry, and whole-rock major and trace element geochemistry they are paired stones from the same meteorite fall (Dunham et al. 2019). Both are olivine-phyric shergottites containing olivine phenocrysts up to $3 \mathrm{~mm}$ in size, with rare pyroxene macrocrysts up to $2 \mathrm{~mm}$ in size. Dunham et al. (2019) characterized the modal mineralogy of LAR 12095/12240 and found the groundmass predominantly comprises olivine $(\sim 16-17$ vol\%), pyroxene (61-62 vol\%), and maskelynite (21-23 vol\%). Minor phosphates, oxides $(\sim 1 \mathrm{vol} \%)$, and sulfides $(\sim 1 \mathrm{vol} \%)$ are also present. Microstructural features of shock metamorphism including abundant melt pockets, veins, and darkened olivine are also observed (Dunham et al. 2019). The oxides include chromite and Ti-magnetite, the phosphates are mainly merrillite, with rare apatite, and the sulfide population is dominated by Fe-rich pyrrhotite. LAR 12095/12240 are characterized as depleted shergottites based on their LREE signature (Dunham et al. 2019). There are currently no constraints on the crystallization age of LAR 12240 and LAR 12095, but Righter et al. (2015) suggest an age range of $\sim 400-550 \mathrm{Ma}$ based on the modeled ${ }^{147} \mathrm{Sm} /{ }^{144} \mathrm{Nd}$ and ${ }^{176} \mathrm{Lu} /{ }^{177} \mathrm{Hf}$ 
source composition of depleted shergottite Dar al Gani 476, which represents a close compositional match. Overall, the samples have been interpreted as the products of closed-system fractional crystallization, following magma emplacement and crystal accumulation (Dunham et al. 2019).

\section{METHODS}

\section{Bulk chemical analyses}

Bulk chips of LAR 12095/12240 and LAR 06319/12011 were processed for bulk chemical analyses in a class 1000 clean room at the University of Manchester using an agate pestle and mortar. The bulk-rock compositions of LAR 06319,64, LAR 12011,6, LAR 12095,8, and LAR 12240,6 were determined by inductively coupled plasma mass spectrometry (ICP-MS) using an Agilent 7700X instrument and inductively coupled plasma optical emission spectroscopy (ICP-OES) using a Thermo iCap 6500 Duo spectrometer, at the Natural History Museum, London. The methods used are similar to those reported in Gregory et al. (2017) and are summarized below. Concentrations of 10 major and minor elements including $\mathrm{Cr}$ were determined by ICP-OES. The bulk-rock major, minor, and trace element chemistry of Tissint has been widely reported in the literature (Chennaoui Aoudjehane et al. 2012; Irving et al. 2012; Balta et al. 2015b), and new analyses of this kind are therefore not repeated here.

Approximately $40 \mathrm{mg}$ of sample was fused with $120 \mathrm{mg}$ of $\mathrm{LiBO}_{2}$ in a $\mathrm{Pt} / \mathrm{Au}$ crucible, and the resulting flux dissolved in $10 \% \mathrm{HNO}_{3}$. Calibration was performed using certified reference materials (CRM) prepared in the same way. Concentrations of 38 trace elements as well as $\mathrm{K}_{2} \mathrm{O}$ were determined by ICP-MS from a separate portion of $\sim 50 \mathrm{mg}$ of powdered sample after $\mathrm{HF}+\mathrm{HClO}_{4}+\mathrm{HNO}_{3}$ digestion. To minimize polyatomic interferences, the instrument was operated with $5 \mathrm{~mL} \mathrm{~min}^{-1}$ He $(99.9995 \%$ purity) in the collision-reaction octopole cell (CRC) as well as with no collision gas entering the CRC. Non-isobaric interferences in the ICP-MS analysis were minimized by tuning $\mathrm{CeO}^{+} / \mathrm{Ce}^{+}$to $<0.2 \%$ (in $\mathrm{He}$ mode) and $\mathrm{Ba}^{++} / \mathrm{Ba}^{+}$ to $<1 \%$ (both modes). Although most polyatomic interferences are negligible in the He mode, additional mathematical corrections were performed to correct for polyatomic interferences on $\mathrm{Eu}, \mathrm{Gd}, \mathrm{Tb}, \mathrm{Hf}, \mathrm{Ta}$, and $\mathrm{W}$ caused by $\mathrm{Ba}, \mathrm{Ce}+\mathrm{Pr}, \mathrm{Nd}$, Dy, Ho, and Er, respectively (Strekopytov and Dubinin 1997; Ferrat et al. 2012). Between 3 and 7 repeat measurements of the samples were conducted on different days and the precision of these replicates is reported to 2 St.dev. in Table 2. The relative standard deviation ranges between 0.1 to $5.2 \%$ for the major elements and 0.2 to $7.5 \%$ for the minor and trace elements. Accuracy of the ICP-OES analysis was checked by analyzing BHVO-2 Basalt and JG-1 Granodiorite, and of the ICP-MS analysis by analyzing BCR-2 Basalt, SY-2 Syenite, JLs-1 Limestone, and JSd-2 Stream Sediment reference materials (Supplemental ${ }^{1}$ Table S1).

\section{Scanning electron microscopy (SEM) and electron probe microanalysis (EPMA)}

Polished thin sections LAR 06319,46, LAR 12011,22, LAR 12095,28, and LAR 12240,17 were optically imaged and then carbon coated for imaging by backscatter electron imagery using an EDAX EDS system on a Phillips FEI XL30 ESEM-FEG at the University of Manchester.

Electron probe microanalysis on polished sections of all samples was carried out using a Cameca SX100 (LAR samples and Tissint quantitative mineral chemical analyses and qualitative element mapping) and a JEOL JXA-8530F (Tissint qualitative and quantitative element mapping) at the University of Manchester. Olivine, pyroxene, plagioclase, spinel, and sulfide compositions were measured in LAR 06319/12011 and LAR 12095/12240. Operating conditions for quantitative analyses in LAR samples using the Cameca SX100 included an acceleration voltage of $15 \mathrm{kV}$, a beam current of $2 \mathrm{nA}(\mathrm{Si}, \mathrm{Fe})$ and $20 \mathrm{nA}(\mathrm{Na}, \mathrm{Mg}, \mathrm{Al}, \mathrm{S}, \mathrm{Cl}, \mathrm{K}, \mathrm{Ca}, \mathrm{Cr}, \mathrm{Mn}$, and Ti) and a spot size of $10 \mu \mathrm{m}$. Quantitative analyses of Tissint using the Cameca SX100 used operating conditions including an acceleration voltage of $15 \mathrm{kV}$, a beam current of $10 \mathrm{nA}(\mathrm{Si}$, $\mathrm{Mg}, \mathrm{Fe}$ ), and $100 \mathrm{nA}(\mathrm{Al}, \mathrm{P}, \mathrm{Ca}, \mathrm{Ti}, \mathrm{Cr}, \mathrm{Mn}$, and Ni), and a spot size of $5 \mu \mathrm{m}$. Major and trace element mapping $(\mathrm{Mg}, \mathrm{Ca}, \mathrm{Al}, \mathrm{P})$ was also undertaken to monitor for zoning of particular elements. Analytical conditions for the mapping were variable and are reported in the captions to the Figures and Supplemental Figures ${ }^{1}$.

\section{Neutron irradiation noble gas: NI-NGMS and Ar-Ar dating}

Bulk heavy halogen $(\mathrm{Cl}, \mathrm{Br}$, and $\mathrm{I})$ measurements and $\mathrm{Ar}-\mathrm{Ar}$ dating of Tissint and LAR 06319,64, LAR 12011,6, LAR 12095,8, and LAR 12240,6 were performed at the University of Manchester following the protocols given in Ruzié-Hamilton et al. (2016) and Clay et al. (2017).
TABLE 2. Bulk-rock major- and trace-element composition of shergottite samples LAR 06319, LAR 12011, LAR 12095, and LAR 12240, measured by ICP-MS and ICP-OES at the Natural History Museum, London

\begin{tabular}{lllllllllll}
\hline & Unit & $n$ & \multicolumn{1}{c}{ LAR } & $\pm(2 \sigma$ & \multicolumn{1}{c}{ LAR } & \pm & \multicolumn{1}{c}{ LAR } & \pm & LAR & \pm \\
& & & 12095 & S.D. $)$ & 12240 & & 06319 & & 12011 & \\
\hline $\mathrm{TiO}_{2}$ & wt $\%$ & 3 & 0.445 & 0.008 & 0.519 & 0.012 & 0.692 & 0.029 & 0.719 & 0.032 \\
$\mathrm{Al}_{2} \mathrm{O}_{3}$ & wt\% & 3 & 5.35 & 0.19 & 5.92 & 0.16 & 5.55 & 0.29 & 5.94 & 0.30 \\
$\mathrm{Cr}_{2} \mathrm{O}_{3}$ & wt\% & 3 & 0.884 & 0.022 & 0.898 & 0.005 & 0.625 & 0.002 & 0.578 & 0.004 \\
$\mathrm{Fe}_{2} \mathrm{O}_{3}$ & wt\% & 3 & 19.3 & 0.6 & 18.7 & 0.4 & 22.8 & 1.15 & 22.4 & 1.13 \\
$\mathrm{MnO}$ & wt\% & 3 & 0.46 & 0.01 & 0.45 & 0.01 & 0.501 & 0.028 & 0.46 & 0.03 \\
$\mathrm{MgO}$ & wt\% & 3 & 18.17 & 0.35 & 17.10 & 0.42 & 15.86 & 0.59 & 15.32 & 0.56 \\
$\mathrm{CaO}$ & wt\% & 3 & 6.10 & 0.18 & 6.50 & 0.17 & 6.36 & 0.26 & 6.55 & 0.32 \\
$\mathrm{Na}_{2} \mathrm{O}$ & wt\% & 3 & 0.75 & 0.03 & 0.84 & 0.03 & 1.09 & 0.07 & 1.17 & 0.07 \\
$\mathrm{~K}_{2} \mathrm{O}$ & wt\% & 3 & 0.014 & 0.002 & 0.0163 & 0.001 & 0.142 & 0.010 & 0.139 & 0.014 \\
$\mathrm{P}_{2} \mathrm{O}_{5}$ & wt\% & 3 & 0.341 & 0.004 & 0.408 & 0.004 & 0.718 & 0.017 & 0.756 & 0.018 \\
$T_{\text {Total }}$ & wt\% & & 99.49 & & 99.29 & & 99.69 & & 99.74 &
\end{tabular}

$\begin{array}{lllllllllll}\mathrm{Li} & \text { ppm } & 3 & 1.55 & 0.07 & 1.53 & 0.03 & 3.28 & 0.04 & 3.39 & 0.08\end{array}$

$\begin{array}{lllllllllll}\text { Be } & \text { ppm } & 3 & 0.0196 & 0.0012 & 0.0228 & 0.0012 & 0.277 & 0.009 & 0.282 & 0.010\end{array}$

$\begin{array}{lllllllllll}\mathrm{K} & \mathrm{ppm} & 3 & 113 & 13 & 135 & 11 & 1175 & 87 & 1153 & 119\end{array}$

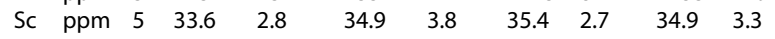

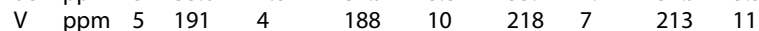

$\begin{array}{lllllllllll}\mathrm{Cr} & \mathrm{ppm} & 3 & 6051 & 150 & 6145 & 37 & 4276 & 12 & 3954 & 24\end{array}$

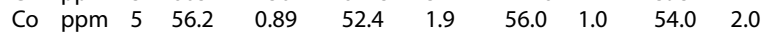

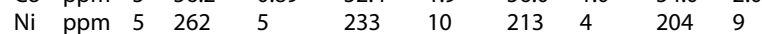

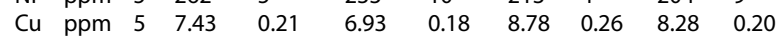

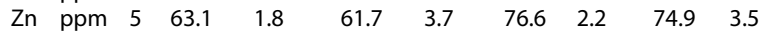

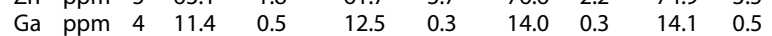

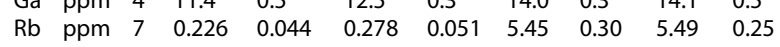

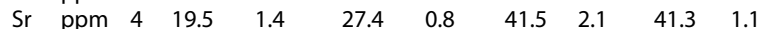

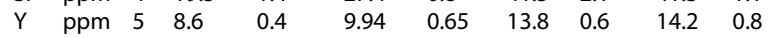

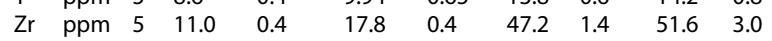

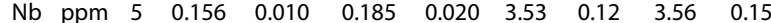

$\begin{array}{llllllllll}\text { Mo ppm } & 3 & 0.058 & 0.006 & 0.176 & 0.014 & 0.109 & 0.007 & 0.188 & 0.016\end{array}$

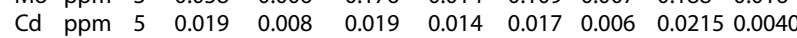

$\begin{array}{lllllllllll}\text { Cs } & \text { ppm } & 4 & 0.0111 & 0.0006 & 0.0082 & 0.0016 & 0.341 & 0.019 & 0.337 & 0.012\end{array}$

$\begin{array}{lllllllllll}\mathrm{Ba} & \text { ppm } & 4 & 1.77 & 0.08 & 2.7 & 0.14 & 24.3 & 0.7 & 25.2 & 0.2\end{array}$

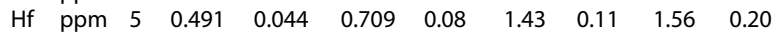

$\begin{array}{llllllll}\text { Ta } & \text { ppm } 5 & <0.015 & <0.015 & 0.133 & 0.032 & 0.138 & 0.046\end{array}$

$\begin{array}{lllllllll}\text { W } & \text { ppm } 3 & <0.1 & <0.1 & 0.417 & 0.022 & 0.351 & 0.008\end{array}$

$\begin{array}{lllllllllll}\mathrm{TI} & \mathrm{ppm} & 4 & 0.0061 & 0.0012 & 0.0116 & 0.0018 & 0.0149 & 0.0030 & 0.0148 & 0.0014\end{array}$

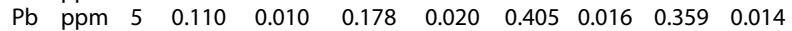

$\begin{array}{lllllllllll}\text { Th } & \text { ppm } & 5 & 0.0197 & 0.0040 & 0.0218 & 0.0078 & 0.389 & 0.034 & 0.405 & 0.040\end{array}$

$\begin{array}{lllllllllll}\mathrm{U} & \text { ppm } & 5 & 0.0068 & 0.0026 & 0.0099 & 0.0054 & 0.097 & 0.011 & 0.102 & 0.012\end{array}$

$\begin{array}{lllllllllll}\text { La } & \text { ppm } & 5 & 0.124 & 0.012 & 0.152 & 0.031 & 2.02 & 0.08 & 2.08 & 0.14\end{array}$

$\begin{array}{lllllllllll}\mathrm{Ce} & \text { ppm } & 5 & 0.383 & 0.036 & 0.455 & 0.075 & 4.84 & 0.31 & 5.01 & 0.43\end{array}$

$\begin{array}{lllllllllll}\mathrm{Pr} & \text { ppm } & 5 & 0.0758 & 0.016 & 0.0871 & 0.017 & 0.716 & 0.062 & 0.732 & 0.060\end{array}$

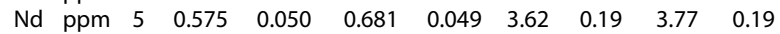

$\begin{array}{llllllllll}\text { Sm ppm } & 5 & 0.470 & 0.038 & 0.561 & 0.054 & 1.38 & 0.11 & 1.42 & 0.16\end{array}$

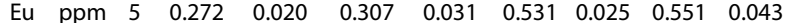

$\begin{array}{lllllllllll}\mathrm{Gd} & \mathrm{ppm} & 5 & 1.18 & 0.08 & 1.38 & 0.13 & 2.26 & 0.11 & 2.35 & 0.17\end{array}$

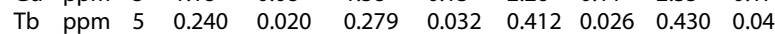

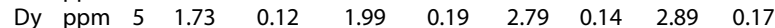

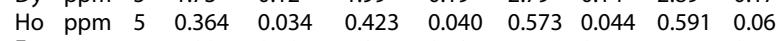

$\begin{array}{lllllllllll}\mathrm{Er} & \mathrm{ppm} & 5 & 1.09 & 0.10 & 1.25 & 0.13 & 1.656 & 0.111 & 1.71 & 0.16\end{array}$

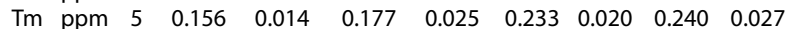

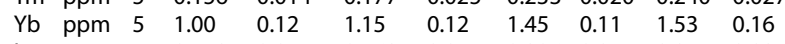

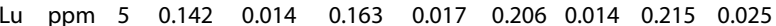

Notes: Major elements are reported as wt\% and trace elements as parts per million Uncertainties are reported as $2 \sigma$ standard deviation. Standard reference material data and detection limits are reported in Supplemental' Table S1. Blank concentration of $\mathrm{Pb}$ has been subtracted from $\mathrm{Pb}$ values.

Sample preparation and irradiation. Terrestrial alteration can be problematic for halogen analysis of some meteorite samples and therefore caution was exercised with sample handling, storage, and preparation techniques to avoid the inclusion of weathered material that may be affected by terrestrial alteration. Signs of visible alteration were avoided, and material was taken from the interior portion of the sample to avoid any inclusion of surface material. Prior to irradiation, samples were crushed into small chips, and aliquots of $\sim 2-7 \mathrm{mg}$ were extracted. Samples were wrapped in $\mathrm{Al}$ foil and, interspersed with irradiation monitor minerals, encapsulated under vacuum in $\mathrm{SiO}_{2}$-glass tubing before packing in $\mathrm{Al}$ canisters for irradiation. Tissint was irradiated at the SAFARI-1 research reactor, South Africa (irradiation MN17, see Supplemental Table S3), continuously over a $24 \mathrm{~h}$ period. Larkman Nunatak samples were irradiated at the Oregon State University (OSU) reactor (irradiation MN14a, see Supplemen- 

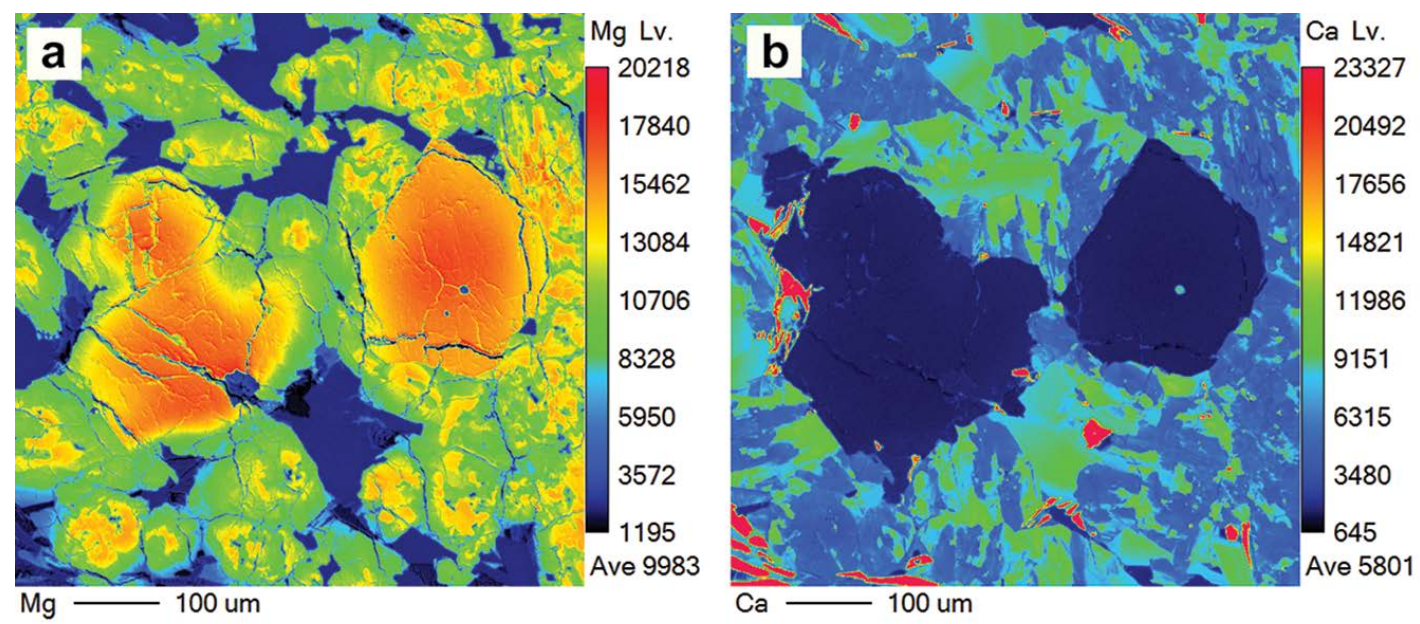

20492

17656

14821

11986

9151
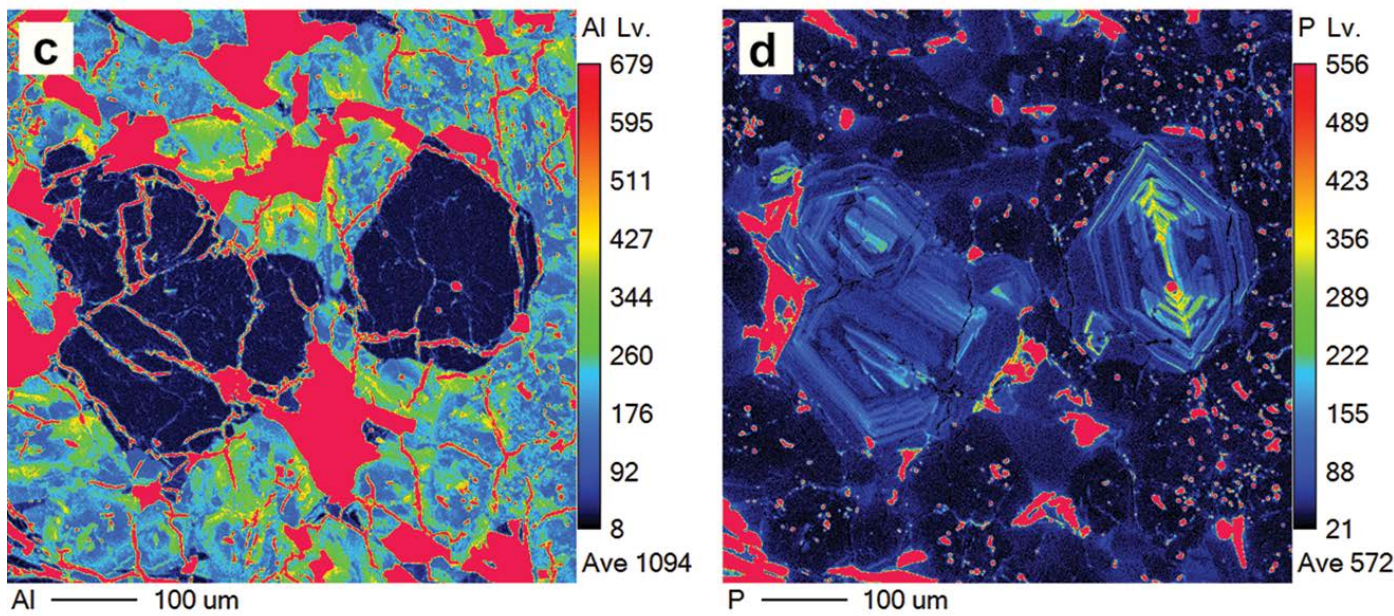

Figure 1. Qualitative false color map of (a) $\mathrm{Mg}$, (b) $\mathrm{Ca}$, (c) $\mathrm{Al}$, and (d) $\mathrm{P}$ in the Tissint shergottite meteorite in counts per second, measured on the JEOL JXA-8530F at the University of Manchester. The same portion of the section is imaged in each panel, comprising central olivine grains in a matrix of pyroxene with variable $\mathrm{Ca}$ compositions. The olivine grains show gradients in $\mathrm{Mg}$ abundance (a) from core to rim and pronounced P-zonation (d). Map conditions: $15 \mathrm{kV}$ acceleration voltage, $1 \mu \mathrm{m}$ beam, $495 \mathrm{nA}$ beam current, $512 \times 512$ pixels, $400 \mathrm{~ms} / \mathrm{pixel}, 2 \mu \mathrm{m} / \mathrm{pixel}$. (Color online.)

tal $^{1}$ Table S3) in a stepped fashion over a 2 month period for a total of $\sim 280 \mathrm{~h}$. The neutron fluence was monitored in each irradiation with conventional ${ }^{40} \mathrm{Ar}-{ }^{39} \mathrm{Ar}$ and I-Xe geochronological standards "Hb3Gr" hornblende (1080.4 $\pm 1.1 \mathrm{Ma}$; Renne et al. 2010) and enstatite separated from the Shallowater aubrite $\left({ }^{129} \mathrm{I}^{127} \mathrm{I}_{\text {initial }}=1.072 \times\right.$ $10^{-4}$, Brazzle et al. 1999). Scapolite minerals ("BB1" and "SP"; Ruzié-Hamilton et al. 2016; Kendrick 2012) were used to monitor epithermal neutron fluence. Thermal and epithermal neutron fluxes were $\sim 9.0 \times 10^{18} \mathrm{n} \mathrm{cm}^{-2}$ and $\sim 1.4 \times 10^{17} \mathrm{n} \mathrm{cm}^{-2}$ for MN17 and $\sim 6.6 \times 10^{18} \mathrm{n} \mathrm{cm}^{-2}$ and $~ 3.4 \times 10^{17} \mathrm{n} \mathrm{cm}^{-2}$ for MN14a.

NI-NGMS measurements and ${ }^{40} \mathbf{A r}-{ }^{39} \mathbf{A r}$ dating. Halogen abundances were determined by neutron irradiation noble gas mass spectrometry (NI-NGMS). This method utilizes the neutron-induced conversion of $\mathrm{Cl}, \mathrm{Br}$, and $\mathrm{I}$ into their respective noble gas isotopes ${ }^{38} \mathrm{Ar}_{\mathrm{Cl}}{ }^{80,82} \mathrm{Kr}_{\mathrm{Br}}$, and ${ }^{128} \mathrm{Xe}_{\mathrm{I}}$. Irradiation of the standards (listed above) with independently known halogen concentrations enables the parent halogen abundances to be accurately calculated from neutron-produced noble gas isotopes (Böhlke and Irwin 1992; Kendrick 2012; Ruzié-Hamilton et al. 2016).

Samples were analyzed using a Thermo Scientific ARGUS VI, a low volume $\left(680 \mathrm{~cm}^{3}\right)$, Nier-type, static vacuum mass spectrometer designed for multi-collection of Ar isotopes using five Faraday cups and a low mass compact discrete dynode (CDD) ion counting multiplier. Gases were released from meteorite samples using a $55 \mathrm{~W}$ Teledyne-CETAC Fusions $\mathrm{CO}_{2}$ laser with a $3 \mathrm{~mm}$ beam diameter. Samples were incrementally step-heated (Ar-Ar) over $\sim 0.2-15 \mathrm{~W}$ or fused (halogens) to $\sim 15 \mathrm{~W}$. After release, gases were purified using SAES NP10 getters and then transferred onto a liquid $\mathrm{N}_{2}$-cooled charcoal finger for five minutes. The finger was warmed to $\sim 60^{\circ} \mathrm{C}$ to release the gases. A trap current of $230 \mu \mathrm{A}$ and an acceleration voltage of $2.5 \mathrm{kV}$ were used. We report typical sensitivities of $1.2 \times 10^{-12} \mathrm{~cm}^{3} \mathrm{fA}^{-1} \mathrm{Ar}, 6.5 \times 10^{-13} \mathrm{~cm}^{3} \mathrm{fA}^{-1}$ $\mathrm{Kr}$, and $8.3 \times 10^{-13} \mathrm{~cm}^{3} \mathrm{fA}^{-1} \mathrm{Xe}$. After nine measurement cycles, isotope abundances were determined by regression to inlet time.

All isotopes were corrected for extraction line blanks, which contributed up to $5 \%$, but typically $<1 \%$ of ${ }^{38} \mathrm{Ar}$ and $<<1 \%$ for ${ }^{80,82} \mathrm{Kr}$ and ${ }^{128} \mathrm{Xe}$. All Ar measurements, for both halogen and Ar-Ar age determinations, were corrected for mass discrimination, the radioactive decay of ${ }^{37} \mathrm{Ar}_{\mathrm{Ca}}$ and ${ }^{39} \mathrm{Ar}_{\mathrm{K}}$ between irradiation and analysis time, and for neutron-produced interference reactions. Corrections for air, trapped, or cosmogenic contributions based on ${ }^{36} \mathrm{Ar}$ were evaluated on a sampleby-sample basis. Corrections for cosmogenic ${ }^{38} \mathrm{Ar}$ for Tissint were $\sim 1-3 \%$ and ranged from $2-22 \%$ for LAR samples (2-4\% in LAR 06319/12011 compared to $15-22 \%$ in LAR 12240/12095). Corrections for air contamination were negligible. Krypton and $\mathrm{Xe}$ isotopes were corrected for neutron-induced fission of ${ }^{235} \mathrm{U}$ using ${ }^{134} \mathrm{Xe}$. Krypton and Xe were corrected for epithermal neutron production using the scapolite monitor minerals BB1 and BB2/SP and the Shallowater aubrite. All relevant irradiation parameters and correction factors are given in the Supplemental ${ }^{1}$ Table S3. The external errors $(2 \sigma)$ are $4 \%$ for $\mathrm{Cl}, 7 \%$ for $\mathrm{Br}$, and $5 \%$ for I, based on the BB1 scapolite monitor.

\section{Natural noble gas measurements}

The natural noble gas composition ( $\mathrm{He}, \mathrm{Ne}, \mathrm{Ar}, \mathrm{Kr}$, and $\mathrm{Xe}$ ) of aliquots (see Supplemental ${ }^{1}$ Table S4 for masses) of LAR 06319,64, LAR 12011,6, LAR 12095,8 , and LAR 12240,6 were determined using the custom-built "Albatros" mass spectrometer at ETH Zürich. The isotope compositions and concentrations 
of all noble gases were measured in standard examinations in a single step at $\sim 1700{ }^{\circ} \mathrm{C}$ (for further details see Riebe et al. 2017). Typical blanks are (in $10^{-11} \mathrm{~cm}^{3}$ STP): $0.003,50,2,6,1900,0.23$ and 0.03 for ${ }^{3} \mathrm{He},{ }^{4} \mathrm{He}$ (increased due to a short exposure of the gas to a pressure gauge mounted in glass), ${ }^{20} \mathrm{Ne},{ }^{36} \mathrm{Ar},{ }^{40} \mathrm{Ar},{ }^{84} \mathrm{Kr}$, and ${ }^{132} \mathrm{Xe}$, respectively. Blank contributions to the total released gas are $<0.04 \%$ for ${ }^{3} \mathrm{He},{ }^{21} \mathrm{Ne}, 2-12 \%$ for ${ }^{4} \mathrm{He},{ }^{20} \mathrm{Ne},<2 \%$ for ${ }^{22} \mathrm{Ne}, \sim 17 / 44 \%$ for ${ }^{36} \mathrm{Ar}$ (enriched/ depleted), $\sim 4 / 15 \%$ for ${ }^{38} \mathrm{Ar}, \sim 7 / 23 \%$ for ${ }^{40} \mathrm{Ar}, 14-37 \%$ for $\mathrm{Kr}$, and $6-40 \%$ for $\mathrm{Xe}$, respectively. The samples were fully degassed in the main temperature steps, as shown with re-extraction steps at a slightly elevated temperature. The natural noble gas isotope composition of Tissint is reported by Wieler et al. (2016) and Avice et al. (2018) and is therefore not repeated here.

\section{Bulk chemistry \\ RESULTS}

Optical and backscattered electron images (BSE) of LAR 12011, 12095, and 12240 are provided in Supplemental ${ }^{1}$ Figures $\mathrm{S} 1-\mathrm{S} 3$ for reference. Element maps of Tissint are provided in Figure 1. Major and trace element sample compositions are reported in Table 2 and plotted in Figure 2 as chondrite-normalized values. Standard data are given in the Supplemental Table S1. There is very good agreement between the enriched LAR 06319/12011 samples. Depleted samples LAR 12095/12240 show slight variation between the two samples (Fig. 2). Our bulk analyses of LAR 06319 are in broad agreement with previously reported major element measurements (Basu Sarbadhikari et al. 2009); within $\sim 3-5 \%$ for most elements, but up to $8 \%$ for $\mathrm{Al}_{2} \mathrm{O}_{3}$. Our analysis of LAR 12095 agrees with data reported in Funk (2016) to within $2-8 \%$ for major elements.

\section{Element mapping}

Major (Mg, Ca, and Al) and minor element (P) maps of Tissint are shown in Figure 1. Minor element distribution, such as $\mathrm{P}$, can provide insight into the magmatic growth history and cooling history of olivine-bearing rocks (Milman-Barris et al. 2008; Welsch et al. 2014; Watson et al. 2015). The olivine macrocrysts in Tissint show gradational concentric zoning in $\mathrm{Mg}$ content of olivine from core to rim, with the highest concentrations in the phenocryst centers (Fig. 1a). Distinctive P zoning is observed in Tissint olivine crystals with well-defined dendritic crystallites in macrocryst cores overgown by fine-scale oscillatory zoning (Fig. 1d). Chromium distribution in Tissint matches the same compositional zones as P (Supplemental ${ }^{1}$ Fig. S4). Olivine in the LAR samples was not mapped in the present study, but Dunham et al. (2019) reported classic P zoning (P-rich core with alternating low- and high- $P$ zones) in olivine from LAR 12095 and poorly developed zoning in LAR 12240. Balta et al. (2013) additionally reported P-zoning in LAR 06139 olivine.

\section{Mineral chemistry}

All of the mineral chemical data are reported in Supplemental ${ }^{1}$ Table S2 and plotted in Figure 3. Balta et al. (2015b) and Dunham et al. (2019) previously reported silicate mineral compositions for samples LAR 12011, 12095, and 12240, which are plotted in Figure 3. Mineral compositions for LAR 06319, detailed by Basu Sarbadhikari et al. (2009), Peslier et al. (2010), and Balta et al. (2013) are also plotted for reference in Figure 3. Minor phases, including oxides (spinel and ilmenite) and sulfide (pyrrhotite), were measured in LAR $12240(\mathrm{n}=19)$, LAR $12095(\mathrm{n}=25)$, LAR $12011(\mathrm{n}=11)$, and LAR $06139(\mathrm{n}=6)$ and are reported in Supplemental Table S2.
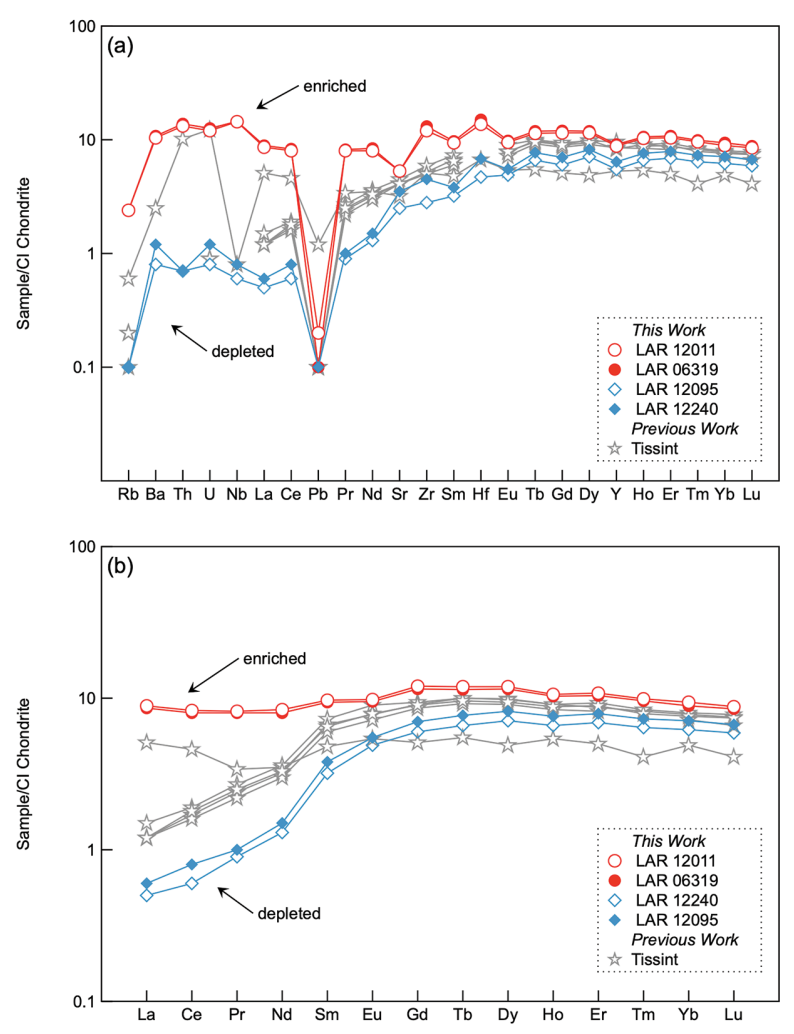

FIGURE 2. Multi-element (a) and rare earth element (b) distribution patterns from enriched shergottite pair LAR 06139/12011, and depleted shergottite pair LAR 12240/12095 from this study, normalized to CI chondrite. Tissint data are shown for comparison as reported in the studies of Avice et al. (2018), Balta et al. (2015), Chennaoui Aoudjehane et al. (2012), and Irving et al. (2012). Normalization values for CI chondrite are from Anders and Grevesse (1989). (Color online.)

Maskelynite. Plagioclase has been converted to maskelynite due to shock metamorphism, as has been observed in martian meteorite samples by other workers (Basu Sarbadhikari et al. 2009; Balta et al. 2013; Dunham et al. 2019). Maskelynite compositions were measured in LAR $12240(\mathrm{n}=65)$, LAR 12095 $(\mathrm{n}=41)$, LAR $12011(\mathrm{n}=49)$, and LAR $06139(\mathrm{n}=9)$ (Fig. 3a). Maskelynite is low-K, with overlapping compositions in both LAR 12240 and LAR 12095 ranging from $\mathrm{An}_{53-71} \mathrm{Ab}_{28-46} \mathrm{Or}_{0.4-1.0}$, in agreement with the range reported by Peslier et al. (2010) and Dunham et al. (2019). LAR 12011/06139 plagioclase is also converted to maskelynite, albeit relatively K-rich compared to the former samples, with up to $\mathrm{Or}_{10}$. The full compositional range observed is $\mathrm{An}_{46-59} \mathrm{Ab}_{38-50} \mathrm{Or}_{2-10}$. The latter is a more restricted range for anorthite content in LAR 06139 than previous studies (Basu Sarbadhikari et al. 2009; Balta et al. 2013), with similarly high K-contents as reported in Balta et al. (2013).

Pyroxene. Pyroxene compositions were measured in LAR $12240(\mathrm{n}=113)$, LAR $12095(\mathrm{n}=77), \operatorname{LAR} 12011(\mathrm{n}=105)$, and LAR $06139(\mathrm{n}=33)$ (Fig. 3b) and show a wide range of compositions. Pyroxene compositions in LAR 12240/12095 overlap, similar to the data of Dunham et al. (2019). The measured compositions are dominated by low $\mathrm{Ca}$-pigeonite with a small number of augite analyses. The full range of compositions 

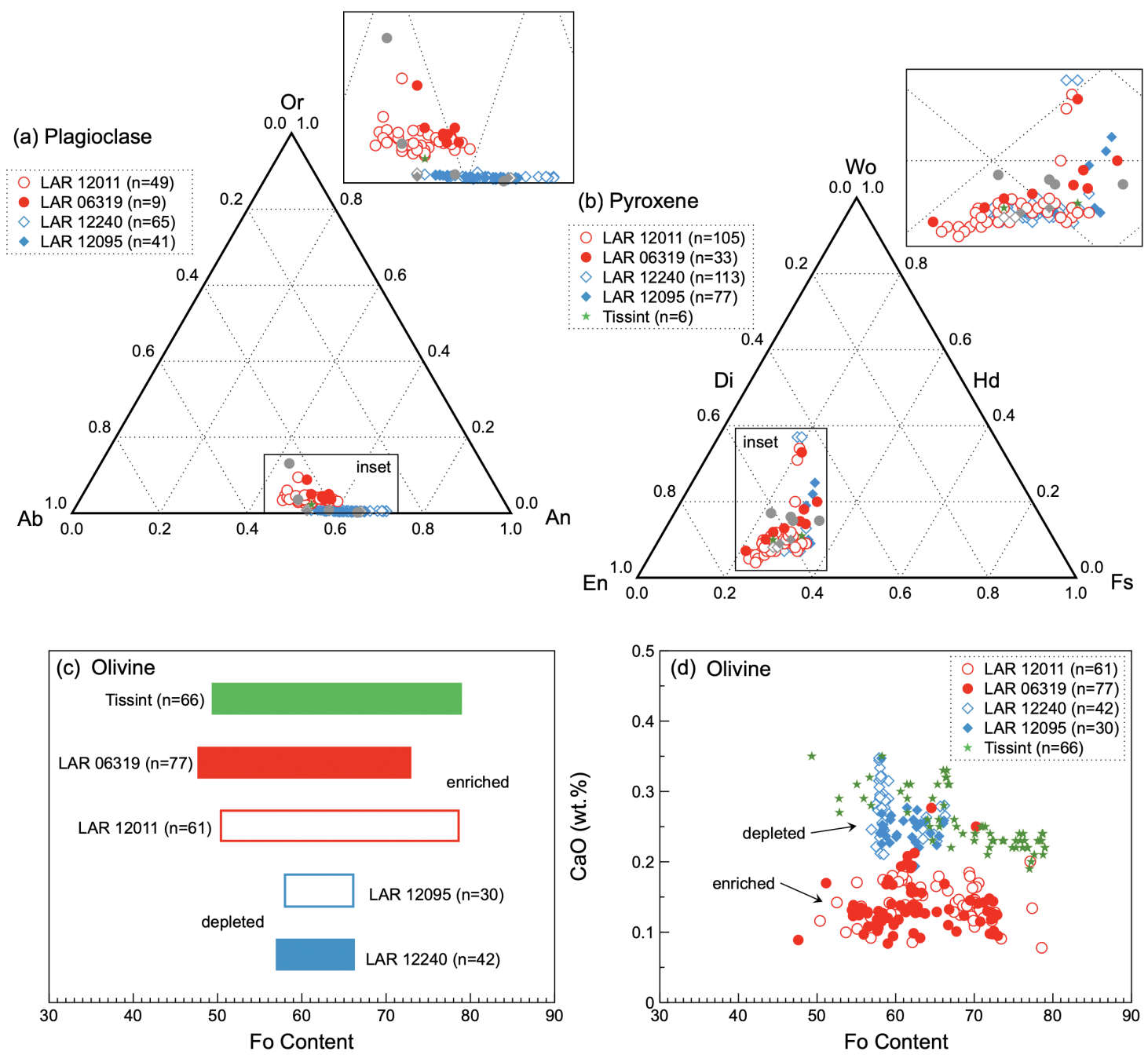

FIGURE 3. Calculated mineral compositions of (a) maskelynite, (b) pyroxene, (c) calculated range of Fo-content of measured olivine, and (d) $\mathrm{CaO}(\mathrm{wt} \%)$ as a function of calculated Fo-content in shergottite samples from this study. Reference mineral compositions from LAR 06139 are shown as gray circles and reference compositions from LAR 12240/12095 are shown as gray diamonds (Basu Sarbadhikari et al. 2009, 2011, 2016; Balta et al. 2013, 2015; Dunham et al. 2019). (Color online.)

is $\mathrm{En}_{44-72} \mathrm{Fs}_{18-35} \mathrm{Wo}_{4-37}$ and Mg\# 62-76. LAR 12011/LAR 06319 also overlap in composition, with a range of $\mathrm{En}_{38-71} \mathrm{Fs}_{17-47} \mathrm{Wo}_{4-36}$ and $\mathrm{Mg} \# 46-73$, and show more variation in their Fe-contents compared with the LAR 12240/12095 pair. Low-Ca pigeonite also dominates, with minor augite present too. A subset of typically more Fe-rich pyroxene measurements from LAR 12011 $(\mathrm{n}=17)$, in contact with a pseudomorphed glass pocket, show a large range of compositions of $\mathrm{En}_{39-69} \mathrm{Fs}_{23-45} \mathrm{Wo}_{4-30}$ and $\mathrm{Mg} \#$ 46-72. Pyroxene crystals in Tissint $(\mathrm{n}=6)$ yield compositions of $\mathrm{En}_{51-64} \mathrm{Fs}_{25-27} \mathrm{Wo}_{8-24}$ and $\mathrm{Mg \#}$ 67-70.

Olivine. Olivine compositions were measured in LAR 12240 $(\mathrm{n}=42)$, LAR $12095(\mathrm{n}=30)$, LAR $12011(\mathrm{n}=61)$, and LAR $06139(\mathrm{n}=77)$ (Figs. 3c and 3d). Olivine compositional ranges between LAR 12240 and 12095 show good overlap, as observed by Dunham et al. (2019). We report a range in compositions of $\mathrm{Fo}_{57-66} \mathrm{Fa}_{34-43}$ and $\mathrm{FeO} / \mathrm{MnO}=51-59$. Olivine cores are typically more Mg-rich than the rims. LAR 12011 and LAR 06319 overlap in composition, but yield more variable olivine compositions, with a full range of $\mathrm{Fo}_{48-79} \mathrm{Fa}_{21-52}$ and $\mathrm{FeO} / \mathrm{MnO}=46-57$. Olivine was measured in Tissint $(\mathrm{n}=66)$ and revealed a range of $\mathrm{Fo}_{52-79}$ $\mathrm{Fa}_{21-47}$ and $\mathrm{FeO} / \mathrm{MnO}$ of $36-47$.

\section{Halogen geochemistry}

Results from all heating experiments are reported in Table 3 and Figures 4 and 5. Chlorine in Tissint $(n=6)$ ranges from 15.9 \pm 3.4 to $26.0 \pm 5.5 \mathrm{ppm}$. Bromine and $\mathrm{I}(\mathrm{n}=4)$ range from $103 \pm$ 22 to $136 \pm 29 \mathrm{ppb}$ and $3.4 \pm 0.7$ to $5.7 \pm 1.1 \mathrm{ppb}$, respectively (Figs. 4a and 4b). Average concentrations (1 $\sigma$ S.D) of $21.2 \pm$ $3.8 \mathrm{ppm} \mathrm{Cl}, 120.8 \pm 14.3 \mathrm{ppb} \mathrm{Br}$, and $4.1 \pm 1.1 \mathrm{ppb}$ I in Tissint (Table 3) are within the range of previously measured halogen concentrations in SNCs (see Rampe et al. 2018 and values and ranges given in Fig. 4 and Table 3), though on the lower side of previously reported abundances.

Depleted shergottites LAR 12240/12095 yield Cl abundances 
TABLE 3. NI-NGMS determined heavy halogen (Cl, Br, and I) abundances for shergottite samples Tissint, LAR 06319, LAR 12011, LAR 12095, and LAR 12240

\begin{tabular}{|c|c|c|c|c|c|c|c|c|c|c|c|}
\hline Sample & Split & $\begin{array}{l}\text { Mass } \\
(\mathrm{mg})\end{array}$ & $\begin{array}{c}\mathrm{Cl} \\
(\mathrm{ppm}) \\
\end{array}$ & $\begin{array}{c}\mathrm{Br} \\
(\mathrm{ppb})\end{array}$ & $\begin{array}{c}\text { I } \\
\text { (ppb) }\end{array}$ & $\begin{array}{c}\mathrm{K} \\
(\mathrm{ppm}) \\
\end{array}$ & $\begin{array}{c}\mathrm{Ba} \\
(\mathrm{ppm})\end{array}$ & $\begin{array}{l}\mathrm{K} / \mathrm{Cl} \\
(\mathrm{wt}) \\
\end{array}$ & $\begin{array}{c}\mathrm{Br} / \mathrm{Cl}(\mathrm{wt}) \\
\times 10^{-3}\end{array}$ & $\begin{array}{c}\mathrm{I} / \mathrm{Cl}(\mathrm{wt}) \\
\times 10^{-3} \\
\end{array}$ & Ref. \\
\hline Tissint & $\mathrm{H}-1$ & 3.3 & $15.9 \pm 3.4$ & $116 \pm 25$ & $3.7 \pm 0.7$ & $229 \pm 41$ & $1.6 \pm 0.3$ & $14.4 \pm 2.6$ & $7.3 \pm 0.3$ & $0.23 \pm 0.07$ & This work \\
\hline Tissint & $\mathrm{H}-2$ & 3.3 & $19.7 \pm 4.2$ & $103 \pm 22$ & $5.7 \pm 1.1$ & $273 \pm 48$ & $1.3 \pm 0.3$ & $13.9 \pm 2.5$ & $5.2 \pm 0.2$ & $0.29 \pm 0.08$ & This work \\
\hline Tissint & $\mathrm{H}-3$ & 5.7 & $25.2 \pm 5.3$ & $136 \pm 29$ & $4.9 \pm 0.9$ & $291 \pm 52$ & $1.9 \pm 0.4$ & $11.6 \pm 2.1$ & $5.4 \pm 0.2$ & $0.19 \pm 0.06$ & This work \\
\hline Tissint & $\mathrm{H}-4$ & 8.1 & $26.0 \pm 5.5$ & $128 \pm 27$ & $3.4 \pm 0.7$ & $290 \pm 51$ & $1.9 \pm 0.4$ & $11.2 \pm 2$ & $4.9 \pm 0.2$ & $0.13 \pm 0.04$ & This work \\
\hline Tissint & $D-1^{c}$ & 6.7 & $20.5 \pm 4.3$ & nd & & $246 \pm 44$ & nd & $12.0 \pm 3.3$ & nd & & This work \\
\hline Tissint & $D-2^{c}$ & 7.1 & $19.9 \pm 4.2$ & nd & & $257 \pm 45$ & nd & $12.9 \pm 3.5$ & nd & & This work \\
\hline Avg. Tissint & & & $21.2 \pm 3.8$ & $120.8 \pm 14.3$ & $4.4 \pm 1.1$ & $265 \pm 25$ & $1.7 \pm 0.3$ & $12.7 \pm 1.3$ & $5.7 \pm 1.1$ & $0.21 \pm 0.07$ & This work \\
\hline LAR12240,6 & $A$ & 2.40 & $15.8 \pm 0.8$ & $62 \pm 4$ & $329 \pm 22$ & $174 \pm 6$ & $2.0 \pm 0.2$ & $11.0 \pm 0.4$ & $3.9 \pm 0.3$ & $20.8 \pm 1.7$ & This work \\
\hline LAR 12240,6 & B & 4.43 & $10.1 \pm 0.5$ & $46 \pm 3$ & $259 \pm 17$ & $133 \pm 4$ & $1.5 \pm 0.1$ & $13.1 \pm 0.4$ & $4.5 \pm 0.4$ & $25.6 \pm 2.1$ & This work \\
\hline LAR 12095,8 & C & 2.37 & $13.0 \pm 0.6$ & $54 \pm 4$ & $78 \pm 5$ & $149 \pm 5$ & $1.8 \pm 0.2$ & $11.5 \pm 0.4$ & $4.1 \pm 0.4$ & $6.1 \pm 0.5$ & This work \\
\hline LAR 12095,8 & 1 & 3.14 & $15.0 \pm 0.7$ & $58 \pm 4$ & $59 \pm 4$ & $145 \pm 5$ & $1.9 \pm 0.2$ & $9.6 \pm 0.3$ & $3.9 \pm 0.3$ & $3.97 \pm 0.30$ & This work \\
\hline LAR 12011,6 & $6 \mathrm{~A}$ & 2.21 & $73.5 \pm 3.5$ & $1303 \pm 91$ & $152 \pm 10$ & $911 \pm 31$ & $19 \pm 1.5$ & $12.4 \pm 0.4$ & $17.7 \pm 1.5$ & $2.07 \pm 0.20$ & This work \\
\hline LAR 12011,6 & $6 \mathrm{~B}$ & 3.50 & $103.7 \pm 4.9$ & $1624 \pm 113$ & $198 \pm 13$ & $1171 \pm 39$ & $22.7 \pm 1.8$ & $11.3 \pm 0.4$ & $15.7 \pm 1.3$ & $1.91 \pm 0.20$ & This work \\
\hline LAR 06319,64 & 1 & 2.97 & nd & $1213 \pm 94$ & $1423 \pm 95$ & $745 \pm 25$ & $15.9 \pm 1.3$ & nd & nd & nd & This work \\
\hline LAR 06319,64 & B & 2.56 & $136.1 \pm 6.4$ & $3061 \pm 215$ & $4 \pm 1$ & $1808 \pm 61$ & $25 \pm 2$ & $13.3 \pm 0.4$ & $22.5 \pm 1.9$ & $0.03 \pm 0.01$ & This work \\
\hline For Reference & Note & & & & & & & & & & \\
\hline Carbonaceous chondrite & 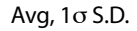 & & $111 \pm 38$ & $362 \pm 39$ & $38 \pm 3$ & 560 & & 5.05 & $3.3 \pm 1.2$ & $0.28 \pm 0.1$ & {$[1]$} \\
\hline BSE & Avg, $1 \sigma$ S.D. & & $25 \pm 9$ & $74 \pm 26$ & $14 \pm 11$ & & & & $3 \pm 1.5$ & $0.56 \pm 0.48$ & {$[1]$} \\
\hline Terrestrial mantle ${ }^{a}$ & Range & & $\sim 1-1600$ & $\sim 1-5900$ & $\sim 2-1000$ & $\sim 200-52000$ & & & $2.9 \pm 0.6$ & $0.06 \pm 0.03$ & {$[2-4]$} \\
\hline Seawater & & & 18800 & 67000 & 58 & 390 & & 0.02 & 3563 & 3.08 & {$[5]$} \\
\hline \multicolumn{12}{|l|}{ Martian surface } \\
\hline Gusev soil & & & 5100 & 20000 & & 3740 & & & & & \\
\hline \multicolumn{12}{|l|}{ Average martian soils } \\
\hline$(\mathrm{n}=11)^{\mathrm{b}}$ & Avg, 1б S.D. & & 5300 & 40000 & & 3407 & & & & & [6] \\
\hline APXS MERA/B & Range & & $100-21300$ & $6000-498000$ & & $40-12200$ & & & & & [7] \\
\hline Odyssey GRS surface ${ }^{d}$ & & & 390 & 2200 & 260 & 305 & & & & & [8] \\
\hline \multicolumn{12}{|l|}{ Martian meteorites } \\
\hline Shergottites $(n=6)$ & & & $14-145$ & $69-890$ & $12-960$ & & & & $4.9-10.8$ & $0.03-122$ & {$[9]$} \\
\hline Nakhlites $(n=7)$ & & & $101-563$ & $80-950$ & $15-1590$ & & & & $0.79-9.1$ & $0.04-6.4$ & {$[10,11]$} \\
\hline Chassigny $(n=1)$ & & & 34 & 97 & 10 & & & & 2.85 & 0.29 & [9] \\
\hline \multicolumn{12}{|c|}{ 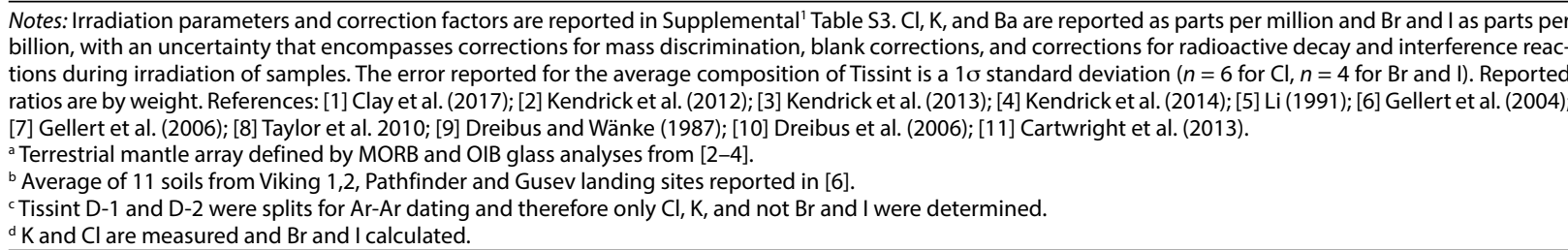 } \\
\hline
\end{tabular}

of $10.1 \pm 0.5$ to $15.8 \pm 0.8 \mathrm{ppm}, 46 \pm 3$ to $62 \pm 4 \mathrm{ppb} \mathrm{Br}$, and a variable distribution of I of $59 \pm 4$ to $78 \pm 5 \mathrm{ppb}$ for LAR 12095 and $259 \pm 17$ to $329 \pm 22 \mathrm{ppb}$ for LAR 12240 (Figs. $4 \mathrm{a}$ and $4 \mathrm{~b}$ ). The enriched shergottites LAR 12011/06139 yield $\mathrm{Cl}$ abundances of $73.5 \pm 3.5$ to $136.1 \pm 6.4 \mathrm{ppm}$ and have heterogeneous $\mathrm{Br}$ $(1213 \pm 94$ to $3061 \pm 215 \mathrm{ppb})$ and $\mathrm{I}(4 \pm 1$ to $1423 \pm 95 \mathrm{ppb})$ abundances (Figs. 4a and 4b). The depleted shergottites (LAR $12240 / 12095$ ) yield more consistent results compared to the enriched pair (LAR 12011/06319) but all abundances are within the range of what has been measured previously for bulk rock halogens in SNC meteorites (data ranges and references are given in Table 3 and plotted for comparison in Fig. 4).

$\mathrm{K}, \mathrm{Ca}$, and $\mathrm{Ba}$ concentrations are derived from the measurement of ${ }^{39} \mathrm{Ar},{ }^{37} \mathrm{Ar}$, and ${ }^{130} \mathrm{Xe}$, respectively. Potassium concentrations in Tissint $(\mathrm{n}=6)$ range from $229 \pm 41$ to $291 \pm 52 \mathrm{ppm}$ (average of $265 \pm 251 \sigma \mathrm{SD}, \mathrm{n}=6$ ). Barium concentrations range from $1.3 \pm 0.3$ to $1.9 \pm 0.4 \mathrm{ppm}$ (average of $1.7 \pm 0.31 \sigma \mathrm{SD}, \mathrm{n}=$ 4), lower than the Ba concentration of 5.9 ppm reported by Avice et al. (2018). Potassium from two measurements of LAR 12240 $(174 \pm 6$ and $133 \pm 4 \mathrm{ppm})$ and LAR $12095(149 \pm 5$ and $145 \pm$ $5 \mathrm{ppm})$ generally agree with the values determined by ICP-MS (Table 1). Barium from LAR $12240(1.5 \pm 0.1$ to $2.0 \pm 0.2 \mathrm{ppm})$ and LAR $12095(1.8 \pm 0.2$ to $1.9 \pm 0.2 \mathrm{ppm})$ also agree with the $\mathrm{Ba}$ abundances determined by ICP-MS. Calcium abundances are not reported due to the timescale between irradiation and analysis ( $>5$ months, $t_{1 / 2}{ }^{37} \mathrm{Ar}_{\mathrm{Ca}} \sim 35.1$ days) and the consequent higher uncertainty associated with these measurements compared to other reported bulk $\mathrm{Ca}$ determinations.

Tissint yields $\mathrm{Br} / \mathrm{Cl}$ and $\mathrm{I} / \mathrm{Cl}$ ratios of $4.9 \pm 0.2$ to $7.3 \pm 0.3$ $\left(\times 10^{-3}\right)$ and $0.13 \pm 0.04$ to $0.29 \pm 0.08\left(\times 10^{-3}\right)$. The highest $\mathrm{I} / \mathrm{Cl}$ ratios for Tissint result from slightly lower $\mathrm{Cl}$ abundances [ 16-20 ppm Cl in two of the measured samples (H-1 and $\mathrm{H} 2$; Fig. 5, Table 3)]. The $\mathrm{K} / \mathrm{Cl}$ ratio of Tissint is reproducible, ranging from $11.2 \pm 2.0$ to $14.4 \pm 2.6$ (Fig. $4 \mathrm{c}$ ).

Depleted shergottites LAR 12240/12095 yield similar $\mathrm{Br} / \mathrm{Cl}$ ratios of $3.9 \pm 0.3$ to $4.5 \pm 0.4\left(\times 10^{-3}\right)$. The $\mathrm{I} / \mathrm{Cl}$ ratios vary by sample, mostly due to the variable I abundances between the pairs: $20.8 \pm 1.7$ and $25.6 \pm 2.1\left(\times 10^{-3}\right)$ for LAR 12240 and 3.9 \pm 0.3 and $6.1 \pm 0.5\left(\times 10^{-3}\right)$ for LAR 12095. Paired, enriched shergottites LAR 12011 and 06139 yield $\mathrm{Br} / \mathrm{Cl}$ ratios of $15.7 \pm$ 1.3 to $22.5 \pm 1.9\left(\times 10^{-3}\right)$. The $\mathrm{I} / \mathrm{Cl}$ ratios are relatively heterogeneous and range from $0.03 \pm 0.01$ to $2.1 \pm 0.2\left(\times 10^{-3}\right)$, due to the three orders of magnitude variation in the measured I abundances between the two samples (Fig. 5). The $\mathrm{K} / \mathrm{Cl}$ ratio of all, both depleted and enriched LAR samples, is broadly similar and ranges from $11.0 \pm 0.4$ to $13.3 \pm 0.4$, with the exception of one lower reported value of 9.6 \pm 0.3 (LAR 12095 split I, Table 3). These ratios are also broadly consistent with Tissint and previ- 

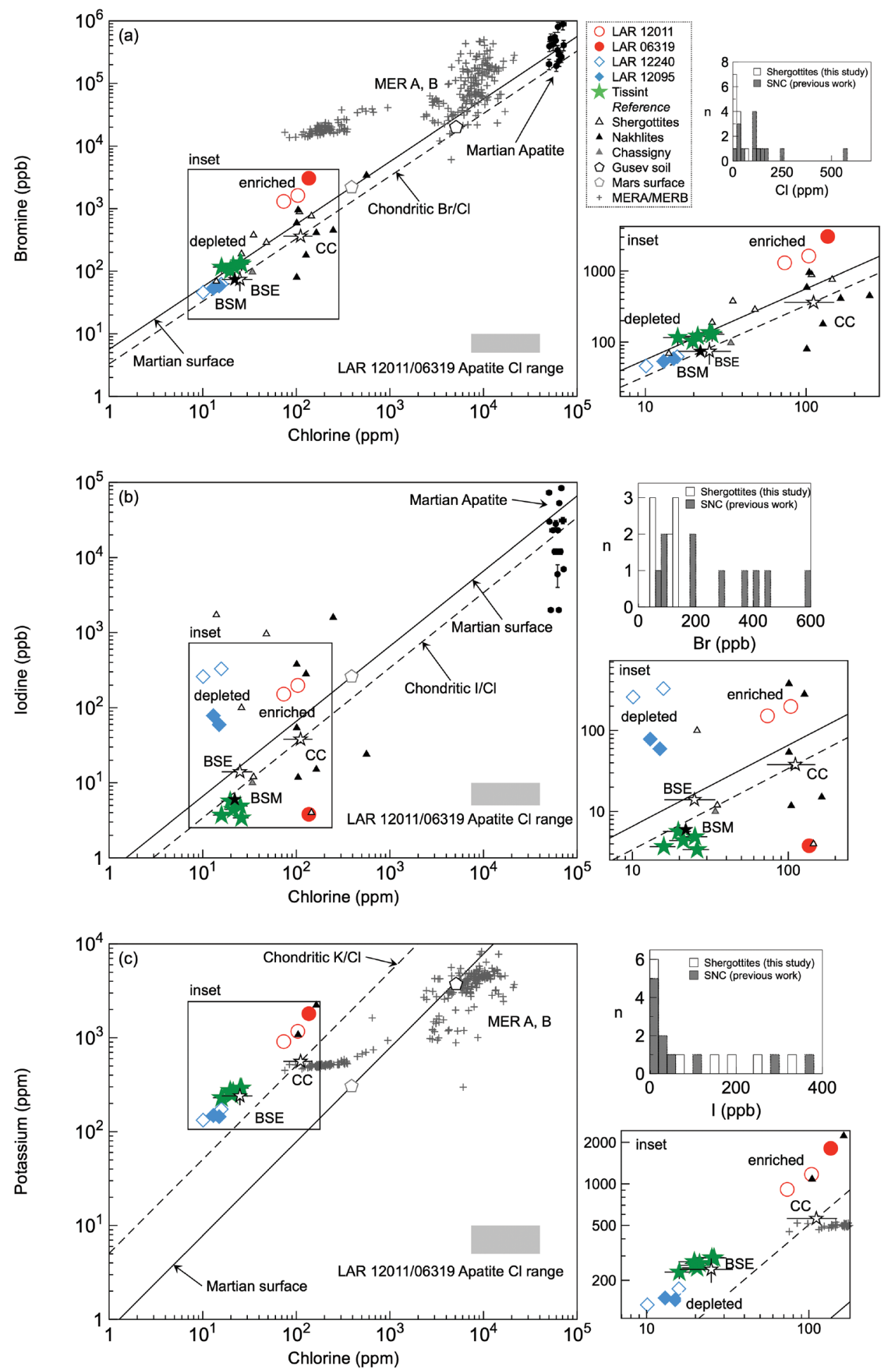

FigURE 4. Bromine (ppb) (a), I (ppb) (b), and $\mathrm{K}(\mathrm{ppm})(\mathbf{c})$ abundances as a function of $\mathrm{Cl}(\mathrm{ppm})$ in martian shergottite meteorites from this study. Log scales are used to accommodate the range in observed concentrations and insets focused on the samples measured in this study to highlight variation between samples. Reference data, including the range of measured Cl concentrations from LAR 12011/06319 apatite (Howarth et al. 2016), regolith breccia NWA 7355 apatite (Bellucci et al. 2017), measured and calculated Mars Odyssey GRS data (Taylor et al. 2010), Mars exploration rover (MERA/MERB) surface data (Gellert et al. 2004, 2006), and measurements of SNC meteorites (Dreibus and Wänke 1987; Dreibus et al. 2006; Cartwright et al. 2013) are plotted for comparison. BSE and carbonaceous chondrite composition (white stars, reported in Clay et al. 2017) and BSM composition (black star, calculated) are given for reference. (Color online.) 


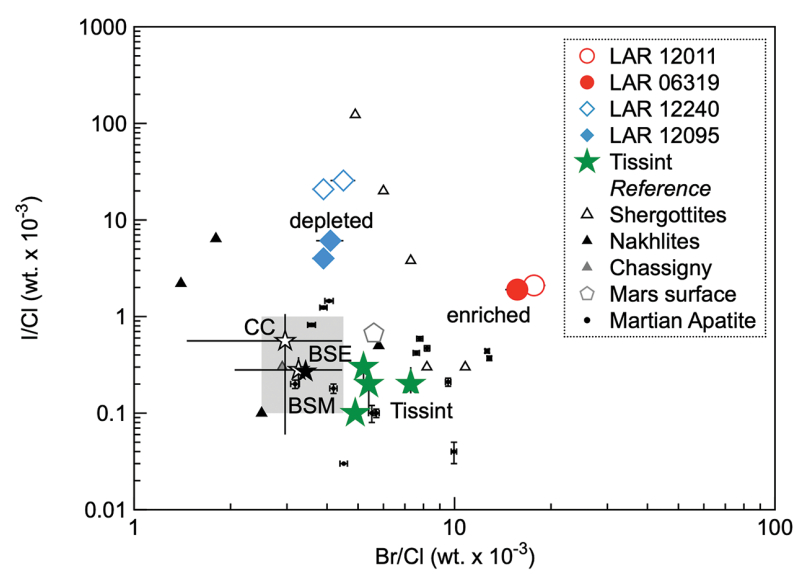

Figure 5. $\mathrm{I} / \mathrm{Cl}\left(\right.$ wt. $\left.\times 10^{-3}\right)$ as a function of $\mathrm{Br} / \mathrm{Cl}\left(\right.$ wt. $\left.\times 10^{-3}\right)$ in martian shergottite samples measured in this study compared with reference martian, meteoritic, and terrestrial material. The gray box is representative of the terrestrial mantle array as defined by measurement of mid-ocean ridge and ocean island basalt glasses (Kendrick et al. 2012, 2013, 2014). Data sources for reference compositions are given in the caption to Figure 4. BSE and carbonaceous chondrite composition (white stars, reported in Clay et al. 2017) and BSM composition (black star, calculated) are given for reference. (Color online.)

ous measurements for the $\mathrm{K} / \mathrm{Cl}$ ratio in shergottites $(\mathrm{K} / \mathrm{Cl} \sim 15$; Wänke and Dreibus 1994).

\section{${ }^{40} \mathrm{Ar}-{ }^{39} \mathrm{Ar}$ dating}

All ${ }^{40} \mathrm{Ar}-{ }^{39} \mathrm{Ar}$ data, including irradiation parameters and all correction factors, are reported in Supplemental ${ }^{1}$ Table S3 and Figure S5. After correction for cosmogenic and atmospheric components (Wiens et al. 1986; Wieler 2002; Avice et al. 2018) were accounted for (see Supplemental ${ }^{1}$ Table S3), age spectra for each sample were plotted. No plateau ages (where plateau steps are defined as contiguous steps comprising $>55 \%$ of the total ${ }^{39} \mathrm{Ar}$ released and overlapping within uncertainty) were determined for any of the samples, indicating disturbed Ar systematics for these shergottite samples. Two splits of the Tissint meteorite (Tissint D1, $6.7 \mathrm{mg}$ and Tissint D-2, $7.1 \mathrm{mg}$, Supplemental ${ }^{1}$ Fig. S5a and S5b) yielded age ranges of 502-1072 and 664-2178 Ma over 20 heating steps and 12 heating steps, respectively. Tissint (D-1) gives four high- $T$ steps that are consistent with the crystallization age of Tissint ( $574 \pm 20 \mathrm{Ma}$; Brennecka et al. 2014) ranging from $549 \pm 3$ to $576 \pm 2 \mathrm{Ma}$, but comprising $<35 \%$ of the total ${ }^{39} \mathrm{Ar}$.

Splits of paired samples LAR $06319(2.36 \mathrm{mg}, \mathrm{n}=17$ steps Supplemental $^{1}$ Fig. S5c) and LAR 12011 (1.99 mg, $\mathrm{n}=16$ steps, Supplemental ${ }^{1}$ Fig. S5d) gave age ranges of 247-389 and 156-342 Ma, respectively. No plateau ages were determined for these samples, which yielded different isochron ages and trapped ${ }^{40} \mathrm{Ar} /{ }^{36} \mathrm{Ar}$ compositions. LAR 06319 yielded an isochron age of $301 \pm 30$ Ma while LAR 12011 yielded an isochron age of 127 $\pm 25 \mathrm{Ma}$. The LAR 12011 age is just within uncertainty of an Ar-Ar age of $163 \pm 13$ Ma determined in pair LAR 06319 (Park et al. 2009). LAR 06319, however, exceeds this age as well as age determinations from other isotopic systems, including $\mathrm{Rb}-\mathrm{Sr}$ (207 $\pm 14 \mathrm{Ma}$; Shih et al. 2009), Sm-Nd (190 $\pm 29 \mathrm{Ma}$; Shih et al. 2009; $183 \pm 12 \mathrm{Ma}$; Shafer et al. 2010), and Lu-Hf(179 $\pm 29 \mathrm{Ma})$, suggesting complex Ar-Ar histories in these paired samples that may be due to shock processes that can disturb Ar distribution.

One split of LAR 12240 (2.01 mg, n=14 steps) was measured and yielded age ranges of 571-1550 Ma. While no plateau age was determined for this sample, a weighted mean average of four high-temperature steps comprising $35 \%$ of the ${ }^{39} \mathrm{Ar}$ yields an age of $581 \pm 2 \mathrm{Ma}$, which is slightly higher than the isochron age of $501 \pm 35 \mathrm{Ma}$ (Fig. S5e). No crystallization age has previously been determined for comparison with paired samples LAR 12240/12095; however, these ages are broadly similar with a previous model estimate of $\sim 400-500 \mathrm{Ma}$ (Righter et al. 2015).

\section{Natural noble gas composition}

Natural noble gas data are reported Supplemental ${ }^{1}$ Table S4. As is typical for shergottites (e.g., Cartwright et al. 2014; Wieler et al. 2016), the light noble gases contain mostly only cosmogenic (cos) $\mathrm{He}$ and $\mathrm{Ne}$ and radiogenic (rad) ${ }^{4} \mathrm{He}$ (Supplemental ${ }^{1}$ Table $\mathrm{S} 4 \mathrm{a})$. The measured ${ }^{3} \mathrm{He}$ is entirely cosmogenic and can be used directly for cosmic ray exposure (CRE) age determinations. Using $\left({ }^{4} \mathrm{He} /{ }^{3} \mathrm{He}\right)_{\cos }=5.65 \pm 0.45$ to correct for ${ }^{4} \mathrm{He}_{\cos }$ we obtain ${ }^{4} \mathrm{He}_{\text {rad }}$. This is very low in all samples and quite constant in the two depleted LAR samples $(12095 / 12240)$ but variable in the two enriched LAR samples $(06319 / 12011)$.

The Ne isotopic compositions of the four LAR samples and Tissint (Wieler et al. 2016) are shown in Figure 6. The two enriched LAR samples contain a small trapped Ne component. It is not possible to distinguish whether it is martian or terrestrial due the proximity of the data points to the cosmogenic $\mathrm{Ne}$ region. For decomposition, we used air Ne. The depleted LAR samples do not show any trapped $\mathrm{Ne}$; however, a contribution from SCR Ne, which is typical for small shergottites (Wieler et al. 2016), is revealed. The measured ${ }^{36} \mathrm{Ar} /{ }^{38} \mathrm{Ar}$ ratios were used to determine ${ }^{38} \mathrm{Ar}_{\text {cos }}$ assuming air $\mathrm{Ar}$ as trapped and a ratio of 0.65 \pm 0.02 as a cosmogenic end-member composition. We used the model predictions by Leya and Masarik (2009, and updates via pers. comm.) based on a physical model for ordinary chondrites, shielding constraints parameterized by the "shielding parameter" $\left({ }^{22} \mathrm{Ne} /{ }^{21} \mathrm{Ne}\right)_{\cos }$ or its inverse, and bulk chemistry of the main target elements for the production of cosmogenic ${ }^{3} \mathrm{He},{ }^{21} \mathrm{Ne}$, and ${ }^{38} \mathrm{Ar}$ (Table 2). For the enriched LAR samples, we adopted $\left({ }^{21} \mathrm{Ne} /{ }^{22} \mathrm{Ne}\right)_{\cos }$ in the range 0.80 to 0.85 (by extrapolation into the cosmogenic Ne region, Fig. 6). For the depleted LAR samples, the measured Ne was used that is affected by SCR-Ne contributions. All $\left({ }^{21} \mathrm{Ne} /{ }^{22} \mathrm{Ne}\right)_{\cos }$ ratios are at the low range expected for GCR-Ne, suggesting, as for many other shergottites (Wieler et al. 2016), a small pre-atmospheric entry size and/or contributions from SCR-Ne. Following Wieler et al. (2016, their Fig. 3), we tested for the presence of SCR-Ne. The elemental ratios Mg/ $(\mathrm{Al}+\mathrm{Si})$ for LAR 06319 and 12011 are 0.40 and 0.38 , respectively. Combined with the deduced $\left({ }^{21} \mathrm{Ne} /{ }^{22} \mathrm{Ne}\right)_{\cos }$, the presence of SCR-Ne is possible but not proven or necessary to explain the data for these meteorites. We assume GCR production only. The opposite, however, is true for the depleted samples LAR 12240 and 12095. Both samples have seen SCR and must originate from the surface of the meteoroid. The CRE ages determined on GCR-Ne systematics alone will hence be underestimated.

The model calculations allow various shielding conditions, but (after excluding extreme and unrealistic radii of $\geq 120 \mathrm{~cm}$ ) 


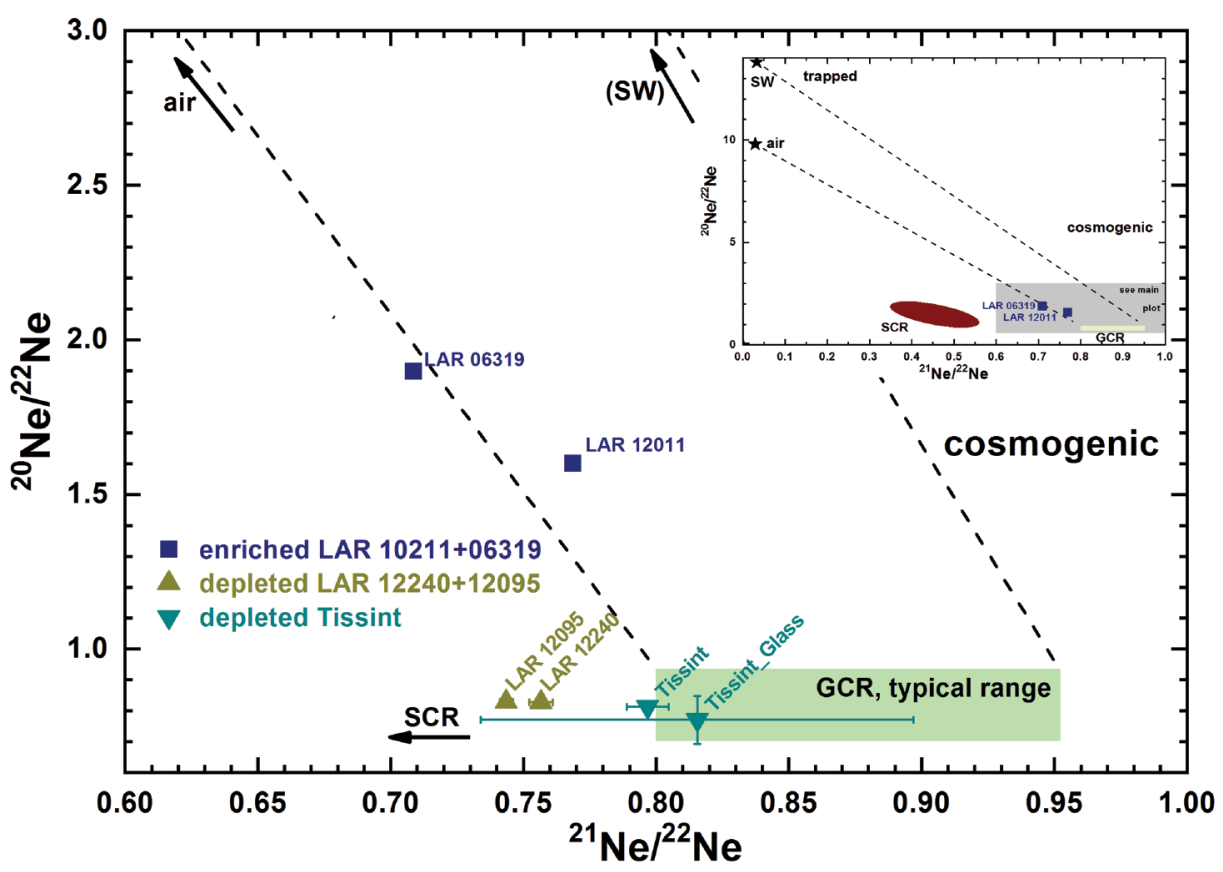

FIGURE 6. Neon three isotope plot showing the four data points for the LAR samples measured in this work and data for Tissint (Wieler et al. 2016). All samples contain dominantly cosmogenic GCR-derived Ne. LAR 06319 and 12011 are paired and distinct from paired LAR 12240 and 12095. Only in the former a small trapped $\mathrm{Ne}$ component is present, which could be air, in view of the $\mathrm{Kr}$ and Xe air contaminations found also in these shergottites. The latter show an additional SCR-derived component. (Color online.)

all conditions include only surface locations for the samples in the meteoroid and essentially all pre-atmospheric radii. For the production rates, we somewhat arbitrarily allow pre-atmospheric radii of a maximum of $20 \mathrm{~cm}$ (which would be a sphere of $108 \mathrm{~kg}$ assuming a density of $3.22 \mathrm{~g} / \mathrm{cm}^{3}$ ). This means for all samples already that the found masses represent only $\leq 0.7 \%$ (LAR 12201 ) or $\leq 0.12 \%$ (the other samples) of the meteoroid, and our assumption is thus very conservative. The uncertainties of the resulting production rates for ${ }^{3} \mathrm{He},{ }^{21} \mathrm{Ne}$, and ${ }^{38} \mathrm{Ar}$ include these allowed shielding conditions (Supplemental ${ }^{1}$ Table S4e). For LAR 12095 and 12240, the model (Leya and Masarik 2009, including update for meteoroids with $\leq 7 \mathrm{~cm}$ radii) predicts no $\left({ }^{21} \mathrm{Ne} /{ }^{22} \mathrm{Ne}\right)_{\cos }$ ratios similar to the measured ratios due to SCR. We use the chemistry-dependent production rates determined for 10 and $20 \mathrm{~cm}$ radii and shielding depth of $0-3 \mathrm{~cm}$ as a rough estimate (Supplemental ${ }^{1}$ Table S4e).

The radiogenic ${ }^{4} \mathrm{He}$ and ${ }^{40} \mathrm{Ar}$ can also be used to determine, albeit only rough maxima, $\mathrm{K}-\mathrm{Ar}$ and $\mathrm{U} / \mathrm{Th}-{ }^{4} \mathrm{He}$ ages using the chemistry in Table 2 and gas concentrations in Supplemental ${ }^{1}$ Table S4. Maximum K-Ar and U/Th- ${ }^{4} \mathrm{He}$ ages for the enriched LAR 12011/06319 are $0.4 / 0.5 \mathrm{Ga}$ and 2/11 Ma, for the depleted LAR 12240/12095, 1.1/1.3 Ga and 66/84 Ma, respectively.

Within their large uncertainties the $\mathrm{Kr}$ and $\mathrm{Xe}$ isotopic compositions of all LAR samples are broadly consistent with a mixture of trapped and cosmogenic $\mathrm{Kr}$ and $\mathrm{Xe}$. The uncertainties are too large to decide whether the trapped component is air or martian but most data points are more consistent with air. There is no evidence for neutron-derived excesses in ${ }^{80,82} \mathrm{Kr}$ and ${ }^{128} \mathrm{Xe}$, in agreement with the assumed small sizes of the meteoroids (see above), the origin of the samples from the meteoroids' surface and small abundances of $\mathrm{Br}$ and I. LAR 12011 shows the least $\mathrm{Xe}$ air contamination and, hence the highest ${ }^{129} \mathrm{Xe} /{ }^{132} \mathrm{Xe}$ ratio and the highest portion of cosmogenic Xe. In an ${ }^{129} \mathrm{Xe} /{ }^{132} \mathrm{Xe}$ vs. ${ }^{36} \mathrm{Ar}_{\mathrm{tr}} /{ }^{132} \mathrm{Xe}$ plot (not shown, cf. Fig. 3B in Cartwright et al. 2014), only LAR 12011 plots on the mixing line between Mars's interior and atmosphere, typical for uncontaminated shergottites, whereas the other three LAR samples plot close to "Earth fractionated atmosphere," which illustrates that the small trapped $\mathrm{Kr}$ and $\mathrm{Xe}$ amounts in these samples are likely air.

Thus, the two pairs of enriched and depleted LAR samples were ejected from Mars at different times. Depleted shergottite Tissint (CRE age $0.7 \pm 0.3 \mathrm{Ma}$, Chennaoui Aoudjehane et al. 2012) and the depleted LAR 12240/12095 (lower limit, see above, $0.84 \pm 0.15 \mathrm{Ma}$, Supplemental ${ }^{1}$ Table S4e) could have been ejected in the same event, whereas LAR 06319/12011 were ejected from Mars later, at $0.35 \pm 0.05 \mathrm{Ma}$ ago.

\section{Data quality and evaluation of potential halogen sources}

The present study documents distinct bulk-rock halogen geochemical characteristics between depleted and enriched shergottite meteorites. Both sets of samples reveal halogen abundances and ratios consistent with what has been previously reported for other shergottite meteorites (e.g., Rampe et al. 2018 and references therein). However, the differences between the enriched and depleted end-members are significant: the depleted shergottites, particularly Tissint, have low halogen abundances that are generally consistent with each other, whereas the enriched shergottites have variable and high $\mathrm{Br}$ concentrations and generally 
higher and also relatively variable I abundances ( $\sim 4$ orders of magnitude). Robust characterization of bulk martian meteorites is a particular challenge for trace and mobile elements like the halogens because most martian meteorites are finds and have variable and sometimes long terrestrial residence times prior to collection, often in hot or cold desert environments. Additionally, the typically small sample masses available for study complicates our ability to robustly characterize the parts per billion to parts per million level halogen abundances normally present in these samples. It is, therefore, particularly important to consider all potential sources of the halogens before attempting to link the measurements to a particular source region or geochemical process. Here, we consider several potential halogen sources and processes, including: terrestrial contamination (i.e., Langenauer and Krähenbühl 1993), martian surface alteration including secondary mineral assemblages (i.e., Bridges et al. 2001), shock metamorphism (Nyquist et al. 2001), the role of primary mineral carrier phases, such as apatite (Howarth et al. 2016; McCubbin et al. 2016) and crustal contamination processes.

Terrestrial alteration. Terrestrial halogen contamination and alteration of meteorites with a prolonged residence at Earth's surface have been documented in both cold desert (Langenauer and Krähenbühl 1993) and hot desert (Clay et al. 2017) environments and can be characterized by either halogen deposition (e.g., I, cold desert) or leaching (e.g., Br, hot desert). The effects of terrestrial contamination can largely be mitigated through sample preparation techniques that avoid inclusion of surface material. While we do not document any secondary alteration assemblages of features such as Ca-veining, previous studies (e.g., Dunham et al. 2019) report elevated $S$ concentrations in cracks and sulfate phases intergrown with phosphates that are likely the result of such alteration processes. Funk (2016) reported more extensive alteration in LAR 12095 compared to LAR 12240 based on elevated $\mathrm{S}$ concentrations. In the case of Tissint, contributions from terrestrial alteration can effectively be ruled out due to the short (months) time between fall and collection. This is evidenced by low and reproducible halogen abundances (Fig. 4, Table 3) between multiple sample splits.

Terrestrial alteration may be suspected by high halogen abundances (e.g., LAR 06319 split I, 1400 ppb I) but the $\mathrm{K} / \mathrm{Cl}$ and $\mathrm{Cl} / \mathrm{La}$ ratios can also be used to discriminate alteration processes (Filiberto et al. 2016a). The $\mathrm{K} / \mathrm{Cl}$ ratio of all shergottite samples in this study range from $9.6 \pm 0.3$ to $14.4 \pm 2.6$, indistinguishable from the $\mathrm{K} / \mathrm{Cl}$ ratio of previously reported shergottite meteorites ( $\mathrm{K} / \mathrm{Cl} \sim 15$; Wänke and Dreibus 1994). The $\mathrm{Cl} / \mathrm{La}$ ratios of the enriched shergottites $(\mathrm{Cl} / \mathrm{La}=43$ and 67 ; Figs. $7 \mathrm{a}$ and $7 \mathrm{~b})$, the most likely to be affected by terrestrial alteration based on their high $\mathrm{Br}$ and I concentrations, are generally consistent with the ratio for the martian interior $(\mathrm{Cl} / \mathrm{La} \sim 52$; Filiberto et al. 2016a). Barium measured by NI-NGMS is consistent within samples and comparable to previous work (e.g., Balta et al. 2015).

With the exception of the heavy noble gases $\mathrm{Kr}$ and Xe, LAR 12240 and LAR 12095 do not seem to be affected by terrestrial alteration based on petrography, geochemistry, and generally low and constant halogen abundances (Fig. 5). The high $\mathrm{Br}$ abundances in LAR 06319 and LAR 12011, as well as one high I measurement in LAR 06319, warrant further consideration, particularly as these are Antarctic meteorites. However, the pe- trography and other geochemical evidence (e.g., $\mathrm{K} / \mathrm{Cl}, \mathrm{Cl} / \mathrm{La}, \mathrm{Ba}$ ) suggest that alteration is unlikely unless it affected exclusively $\mathrm{Br}$ (and I in one sample), but did not modify $\mathrm{Cl}$ and other mobile elements like $\mathrm{Ba}$ and $\mathrm{K}$.

Secondary alteration assemblages. There is abundant evidence in the SNC meteorite collection for the presence of secondary mineral assemblages (Bridges et al. 2001). These minor phases ( $\leq 1 \mathrm{vol} \%)$, in the form of sulfate, carbonate, halite, and clay minerals, provide a record of fluid-rock and surface reservoir interaction on the martian surface. Unlike terrestrial alteration, which can typically be avoided through sample preparation techniques, martian secondary alteration phases cannot easily be avoided in bulk analyses, are a potential host of halogens (e.g., halite), and can obscure primary magmatic signature(s). Shergottites are not known to contain secondary mineral assemblages (Hallis et al. 2017), based on overall lower water contents, compared to the nakhlites and the orthopyroxenite ALHA 84001 (Karlsson et al. 1992; Bridges et al. 2001), though Steele et al. (2018) describe likely mineral-fluid reactions in Tissint. The martian surface is comprised of dust, rocks, and soil of a basaltic composition similar to shergottites and rich in salts (Gellert et al. 2004). The relationship between the surface composition of Mars and the observed alteration assemblages in SNC meteorites is unclear; however, the role of brines and evaporative processes has been suggested to be important in the formation of these assemblages (Rao et al. 2005). The heavy halogen composition of these alteration assemblages is not currently well constrained, particularly for $\mathrm{I}$. However, $\mathrm{Cl}$ and $\mathrm{Br}$ data from nakhlite alteration veins [7700 ppm Cl, $151 \mathrm{ppm} \mathrm{Br}, \mathrm{Br} / \mathrm{Cl}(\mathrm{w} / \mathrm{w}) \sim 0.02$; Rao et al. 2005] suggest similar compositions to terrestrial brines, in excess of abundances and ratios measured $(\sim 350 \times \mathrm{Cl}, \sim 1100 \times$ $\mathrm{Br}$, and $\sim 4-5 \times \mathrm{Br} / \mathrm{Cl})$ in the depleted shergottite samples here. The ratio of $\mathrm{Cl} / \mathrm{La}$ in enriched shergottites $(\mathrm{Cl} / \mathrm{La}=43$ and 67 ; Fig. 7) is similar to the ratio for the martian interior $(\mathrm{Cl} / \mathrm{La} \sim 52$; Filiberto et al. 2016a) and lower than the range for crustal regolith breccias $(\mathrm{Cl} / \mathrm{La}=97-190$; where a high $\mathrm{Cl} / \mathrm{La}$ ratio is indicative of alteration), which are considered to contain a component of martian surface material.

Martian alteration assemblages probably do not contribute to the halogen budget of the depleted shergottite samples, but cannot be definitively ruled out as contributors to the halogen budget of the enriched shergottite samples LAR 06319/12011, due to the similarity in the proportion of $\mathrm{Br}$ to $\mathrm{Cl}$ present in these samples to measured secondary salt vein material in other martian meteorites $\left(\mathrm{Br} / \mathrm{Cl} \sim 20 \times 10^{-3}\right)$. We suggest that it is unlikely, however, despite the similarity in $\mathrm{Br} / \mathrm{Cl}$ ratios, due to a lack of petrographic evidence for alteration assemblages in these samples, coupled with $\mathrm{K} / \mathrm{Cl}$ and $\mathrm{Cl} / \mathrm{La}$ ratios that are different to martian surface values.

Iodine and the role of shock. All martian meteorites show evidence of shock metamorphism, resulting from the large-scale impacts that ejected them from the surface of Mars (Nyquist et al. 2001). Shock implantation of martian atmospheric gases into meteorites (Ocker and Gilmour 2004; Cartwright et al. 2010) occurred with shock pressures ranging from 15 to $45 \mathrm{GPa}$ (Fritz et al. 2005). This is evidenced particularly in ${ }^{129} \mathrm{Xe} /{ }^{132} \mathrm{Xe}$ ratios that exceed that of solar $(1.0450 \pm 0.0050$; Crowther and Gilmour 2013) or the trapped "planetary" component Q-Xe (1.042 \pm 

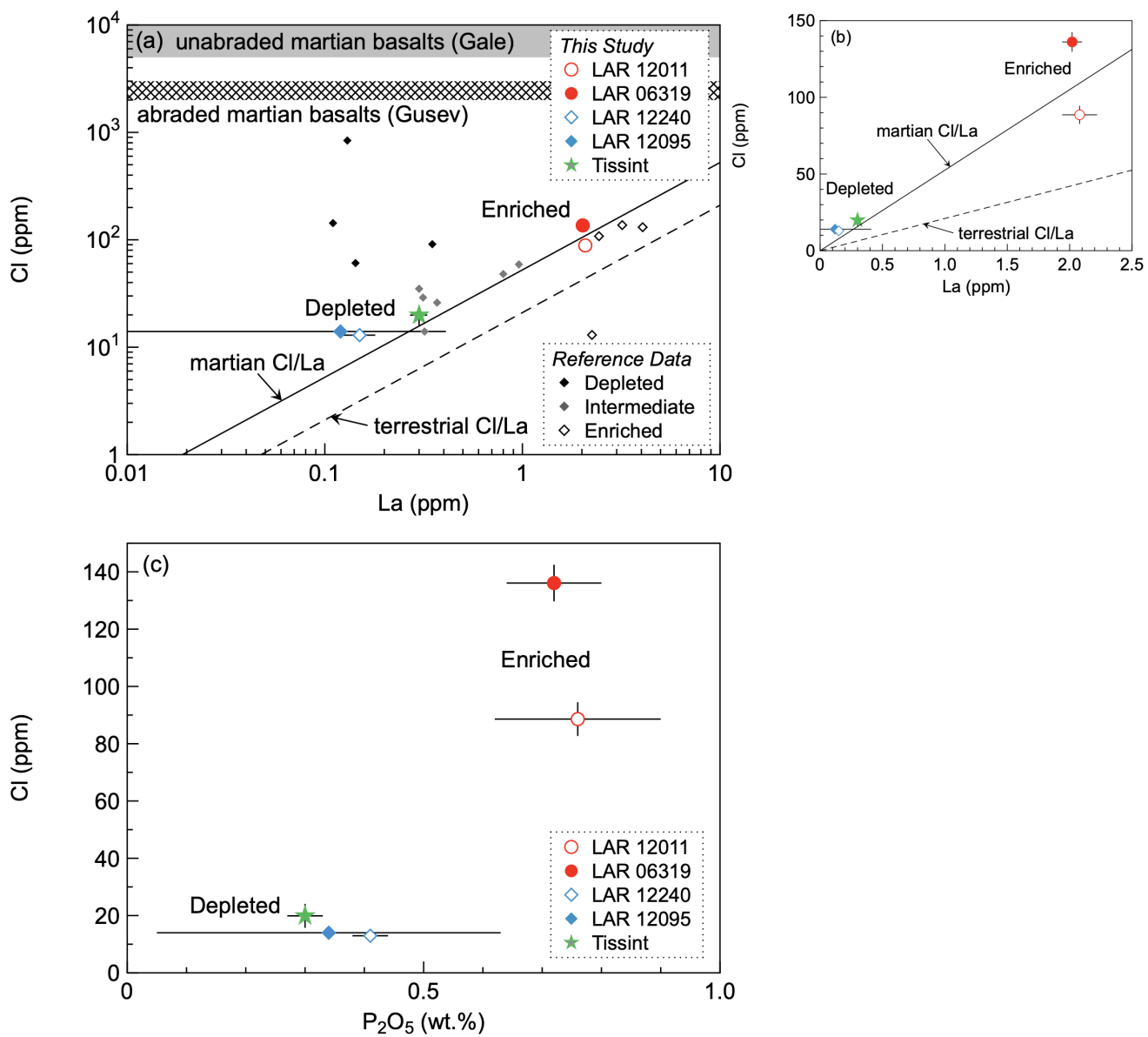

FigURE 7. (a) $\mathrm{Cl}(\mathrm{ppm})$ as a function of $\mathrm{La}(\mathrm{ppm})$ abundance in martian depleted and enriched shergottites from this study with reference data for depleted intermediate and enriched shergottites shown. $\mathrm{Cl}$ and $\mathrm{La}$ are determined in this study with the exception of the La abundance for

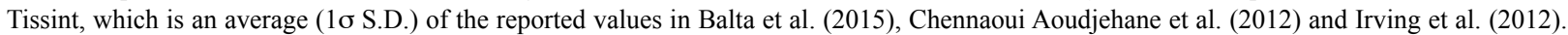
(b) Close-up of the data from this study on a linear scale to highlight the variation between pairs. The terrestrial $\mathrm{Cl} / \mathrm{La}(21.5) \mathrm{and} \mathrm{martian} \mathrm{Cl} / \mathrm{La}$ $(\sim 52.5)$ ratios are reported in Filiberto et al. (2016). The $\mathrm{Cl}$ range for abraded Gusev basalts is shown and taken to represent martian surface basalts with surface coatings or alteration removed (i.e., abraded / "ratted" by the rock abrasion tool; Gellert et al. 2006). The Cl range for unabraded Gale basalts is shown and taken to represent $\mathrm{Cl}$ abundances present in martian surface alteration products (Schmidt et al. 2009, 2014). Low Cl/La ratios may indicate degassing and high $\mathrm{Cl} / \mathrm{La}$ ratios may indicate alteration or contamination. (c) Chlorine as a function of bulk $\mathrm{P}_{2} \mathrm{O}_{5}$ (wt\%) in depleted and enriched shergottites. Bulk $\mathrm{P}_{2} \mathrm{O}_{5}$ for Tissint is from Avice et al. (2108). Rather than a correlation between $\mathrm{Cl}_{\text {and }} \mathrm{P}_{2} \mathrm{O}_{5}$, which would indicate apatite as a sole carrier of $\mathrm{Cl}$ in these samples, we observe grouping of enriched samples with high $\mathrm{Cl}$ and $\mathrm{P}_{2} \mathrm{O}_{5}$ compared to lower $\mathrm{Cl}$ and $\mathrm{P}_{2} \mathrm{O}_{5}$ in depleted shergottites. Reference data for previous shergottite studies from the following sources: Dreibus and Wänke (1985, 1987); Dreibus et al. (1996, 2000, 2003); Lodders (1998); Zipfel et al. (2000); Shirai and Ebihara (2004); Bogard et al. (2010); Burgess et al. (2013); Cartwright et al. (2013); Filiberto et al. (2012); Meyer (2014). (Color online.)

0.002; Busemann et al. 2000) preserved in glass, opaque mineral phases, maskelyinite, and pyroxene in martian meteorites (Ocker and Gilmour 2004; Cartwright et al. 2010).

Iodine, as a large ion, would be particularly susceptible to mobilization and redistribution due to shock metamorphism. Iodine abundances measured in the samples in this study are variable with the exception of Tissint $(4.1 \pm 1.1 \mathrm{ppb} \mathrm{I}, 1 \sigma$, $\mathrm{n}=4$ ). The enriched shergottite samples range from $\sim 4-200$ $\mathrm{ppb}$, with the exception of one of the subsamples of LAR 06319 (split I, $1400 \mathrm{ppb}$ I), while depleted shergottite samples LAR $12095 / 12240$ range from $\sim 60-330 \mathrm{ppb}$ I. This variation of $\sim 4$ orders of magnitude could result from shock processes and a relationship between the ${ }^{129} \mathrm{Xe} /{ }^{132} \mathrm{Xe}$ ratio and I abundance might therefore be expected. The ${ }^{129} \mathrm{Xe} /{ }^{132} \mathrm{Xe}$ ratios of depleted shergottites are $0.989 \pm 0.28$ and $1.014 \pm 0.044$ and of enriched shergottites are $1.006 \pm 0.019$ and $1.34 \pm 0.13$. Avice et al. (2018) report ${ }^{129} \mathrm{Xe} /{ }^{132} \mathrm{Xe}$ ratios of $1.147 \pm 0.348$ to $2.030 \pm 0.012$ in bulk samples and glass separates (the highest ratios are preserved in Tissint glass). With only one enriched sample (LAR 12011) and one depleted sample (Tissint) in excess of the solar, air, or trapped planetary ${ }^{129} \mathrm{Xe} /{ }^{132} \mathrm{Xe}$ values, and no correlation with I concentration, the role of shock on the I budget is difficult to assess here. Further halogen and noble gas measurements on variably shocked martian meteorites, including I abundances in specific mineral phases with documented excesses in ${ }^{129} \mathrm{Xe} /{ }^{132} \mathrm{Xe}$ (Cartwright et al. 2010, 2014), will help elucidate the influence 
that shock has on I (re)distribution in future studies.

Halogen carrier phases and mineralogical control. Constraining particular mineralogical control(s) on halogen abundances can be difficult because measuring halogens in major rock-forming, but halogen-poor, silicate minerals, such as olivine and pyroxene, can be challenging. The effect of volumetrically minor but halogen-rich phases, such as apatite, on the bulk halogen signature of meteorites is more straightforward to estimate. Complete $\mathrm{Cl}, \mathrm{Br}$, and I data sets for apatite are uncommon; however, Bellucci et al. (2017) report apatite compositions from enriched (including LAR 12011) and depleted shergottites that can be used to estimate if apatite might in principle account for the halogen abundances and distributions observed here. Figure 8 shows the relative contributions of varying modal proportions of apatite on bulk-rock halogen abundances for "halogen-rich" (enriched shergottite LAR 12011; Bellucci et al. 2017) and "halogen-poor" (depleted shergottite SaU 005; Bellucci et al. 2017) apatite compositions. The $\mathrm{Br}$ and I composition of Tissint could be accounted for by $\sim 0.1 \mathrm{vol} \%$ (I) to $1.7 \mathrm{vol} \%(\mathrm{Br})$ apatite, but requires $\sim 13.5 \mathrm{vol} \%$ for $\mathrm{Cl}$, suggesting a simple apatite control does not adequately explain our data. We note that the halogen composition of merrillite reported by Bellucci et al. (2017) for Tissint is similar to the apatite composition for depleted shergottites and therefore may represent a reasonable halogen carrier. Depleted samples LAR 12240/LAR 12095 would require apatite to be present in quantities between $\sim 0.6$ to $11 \mathrm{vol} \%$ of the rock to account for the full range of bulk halogen abundances in these samples. Enriched shergottites LAR 06319/LAR 12011 would require apatite abundances of 0.1 and $2.1 \mathrm{vol} \%$ for $\mathrm{Cl}$ and $\mathrm{Br}$, respectively, but up to $40 \mathrm{vol} \%$ of apatite to account I. Given the significant variation in apatite composition, from halogen-rich chlorapatite to more halogen-poor $\mathrm{OH}$-apatite (e.g., Bellucci et al. 2017) we suggest that apatite is likely an important halogen carrier phase, though additional carrier phase(s) or secondary process(es) are required to account for the discrepancy in $\mathrm{Cl}$ and $\mathrm{Br} / \mathrm{I}$ concentrations and $\mathrm{Br} / \mathrm{Cl}$ and $\mathrm{I} / \mathrm{Cl}$ ratios, between apatite and bulk martian meteorites. Other potential halogen sites within the samples include grain boundary networks and defects or inclusions in olivine or pyroxene, which could account for the variation in ratios between bulk samples and apatite. This is evidenced by the relationship between $\mathrm{Cl}$ and $\mathrm{P}_{2} \mathrm{O}_{5}$. Rather than a positive correlation, which would indicate apatite as the sole carrier for $\mathrm{Cl}$ in these samples (Fig. 7c), we observe the depleted shergottites clustering in relatively low bulk $\mathrm{Cl}$ vs. $\mathrm{P}_{2} \mathrm{O}_{5}$ space, distinct from the enriched shergottites that have higher coupled $\mathrm{P}_{2} \mathrm{O}_{5}$ and $\mathrm{Cl}$ abundances.

Crustal contamination. The halogen concentrations in the enriched shergottites are relatively high compared with the depleted shergottites, but are also variable. The source of the REE enrichments in these samples is currently an issue of some debate, with suggestions ranging between contributions from an enriched mantle source (Symes et al. 2008) and the role of crustal contamination of shergottite magmas (Herd et al. 2002). On Mars, like Earth, halogens are concentrated in the crust relative to the mantle and, therefore, the effects of crustal contamination of a magma can possibly be discriminated. Previous work on stable isotope variations in martian samples, (e.g., $\delta^{34} \mathrm{~S}$, Franz et al. 2014; $\delta^{37} \mathrm{Cl}$, Williams et al. 2016), supports interaction of magma with the martian crust. However, models of magma-crust mixing
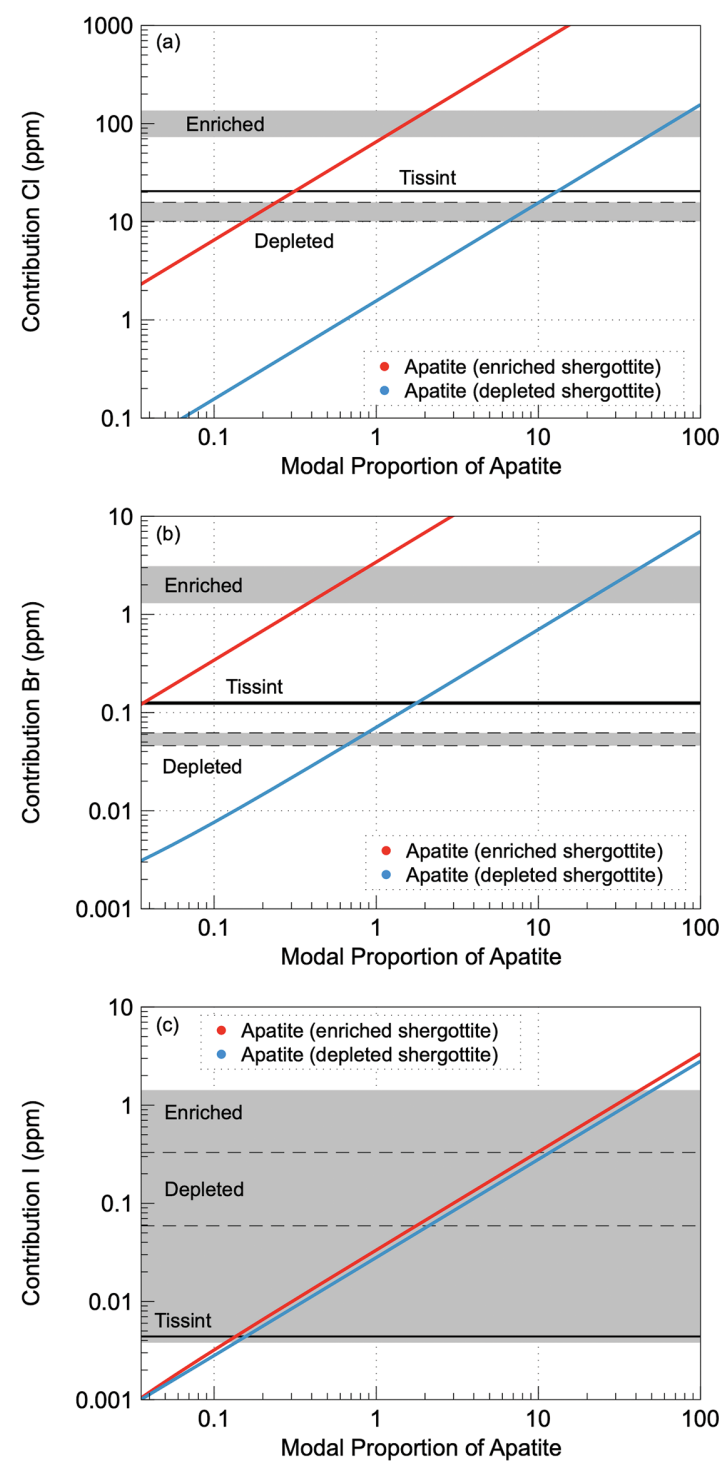

FIGURE 8. The potential contribution of apatite (a) $\mathrm{Cl}$, (b) $\mathrm{Br}$, and (c) I to the bulk halogen budget of depleted and enriched shergottite meteorites in this study. "Enriched" (red line) and "depleted" (blue line) apatite compositions are from Bellucci et al. (2017) represented by an average composition of LAR 12011 and a single measurement of $\mathrm{SaU} 005$, respectively. The gray field shows the range of halogen compositions of enriched shergottites in this study, the gray field bounded by dashed black line represents the range for depleted shergottites and the solid black line is the average composition of Tissint. Apatite is likely the dominant halogen host but cannot account for $\mathrm{Cl}, \mathrm{Br}$, and $\mathrm{I}$ abundances or proportions in all samples. There is likely a much wider range of halogen compositions in martian apatite that may account for the bulk composition, however interpretation is currently limited by a paucity of complete $\mathrm{Cl}, \mathrm{Br}$, and I measurements of apatite. (Color online.)

and assimilation between depleted shergottite compositions and regolith breccia NWA 7034 (Brandon et al. 2017), the latter as an analog for the ancient martian crust, do not support crustal contamination and suggest that the REE enrichment is a feature of the primary mantle source. 
Here, we observe consistently elevated $\mathrm{Br}$ (up to $\sim 3000 \mathrm{ppb}$ ) and variable, but elevated, I abundances ( 4-1423 ppb) in enriched samples (LAR 06319/12011) that could indicate the contamination of a depleted shergottite magma by martian crustal material. The $\mathrm{Br} / \mathrm{Cl}$ and $\mathrm{I} / \mathrm{Cl}$ ratios of enriched shergottites are distinct from depleted shergottites and higher than both carbonaceous chondrites and the $\mathrm{Br} / \mathrm{Cl}$ ratio of the martian surface (Taylor et al. 2010; Figs. $4 \mathrm{a}$ and $4 \mathrm{~b}$ ). The $\mathrm{K} / \mathrm{Cl}$ ratio of enriched shergottites, however, is inconsistent with that of the martian surface (Fig. 4c). Additionally, the $\mathrm{Cl} / \mathrm{La}$ ratio of enriched shergottites is low and consistent with that of the putative martian interior (Fig. 7; Filiberto et al. 2016a). Interaction with the martian surface is not evidenced, as this would require a high $\mathrm{Cl} / \mathrm{La}$ ratio $(\mathrm{Cl} / \mathrm{La}>100)$. Crustal contamination is therefore not thought to be important to the halogen signature of the enriched shergottites studied here on the basis of the different $\mathrm{K} / \mathrm{Cl}$ and $\mathrm{Cl} / \mathrm{La}$ ratios, but cannot be conclusively ruled out.

\section{DISCUSSION}

\section{Halogen geochemistry of the depleted vs. enriched shergottites}

Depleted shergottites Tissint, LAR 12240, and LAR 12095 yield halogen abundances that range from 10 to $26 \mathrm{ppm} \mathrm{Cl}, 46$ to $136 \mathrm{ppb} \mathrm{Br}$, and 3 to $329 \mathrm{ppb}$ I (Figs. 4a and 4b). Enriched shergottites LAR 12011 and LAR 06139 yield $\mathrm{Cl}$ abundances 74 to $136 \mathrm{ppm} \mathrm{Cl}, 1303$ to $3061 \mathrm{ppb} \mathrm{Br}$, and 4 to $1423 \mathrm{ppb} \mathrm{I}$ (Figs. 4a and 4b). In general, depleted shergottites yield more consistent results compared to the enriched shergottites, yet all are within the range of previously reported bulk martian halogens (Figs. 4 and 9) from meteorites. Enriched shergottites are more halogen-rich than depleted shergottites (Fig. 9) and show similar CI-chondrite relative enrichment/depletion abundance patterns to other mobile, incompatible lithophile elements (e.g., $\mathrm{Ba}, \mathrm{Rb}$; Figs. 2a and 9) suggesting similar behavior. Significant variation in I abundance is seen across both enriched and depleted shergottites and ranges from $\sim 0.1$ to $25 \times \mathrm{CI}$ chondrite abundance and may reflect the variety of factors that may affect I (as discussed above). Our results suggest the enriched and depleted shergottite mantle sources have distinct halogen geochemical signatures. Moreover, the reproducible halogen abundances in the Tissint meteorite in particular offer an opportunity to better understand the halogen geochemistry of the martian mantle.

\section{Tissint as a proxy for the martian mantle}

As an unaltered meteorite fall with reproducible halogen abundances between multiple subsplits, the Tissint meteorite halogen composition can be used to estimate the halogen composition of the depleted shergottite mantle source. Before doing so, it is useful to briefly review what is known about the petrogenesis of the Tissint meteorite for wider context.

Tissint petrogenesis. There has been some discussion in the literature about the origin of the olivine macrocrysts in Tissint, i.e., as either phenocrysts sensu stricto (Liu et al. 2016), grown in chemical equilibrium with their host rock, or as antecrysts (Balta et al. 2015a). The arguments of Liu et al. (2016) are partly based on a lack of evidence of resorption in fine-scale P zoning in olivine. Phosphorous is a particularly useful element to constrain crystallization kinetics in olivine because it diffuses relatively

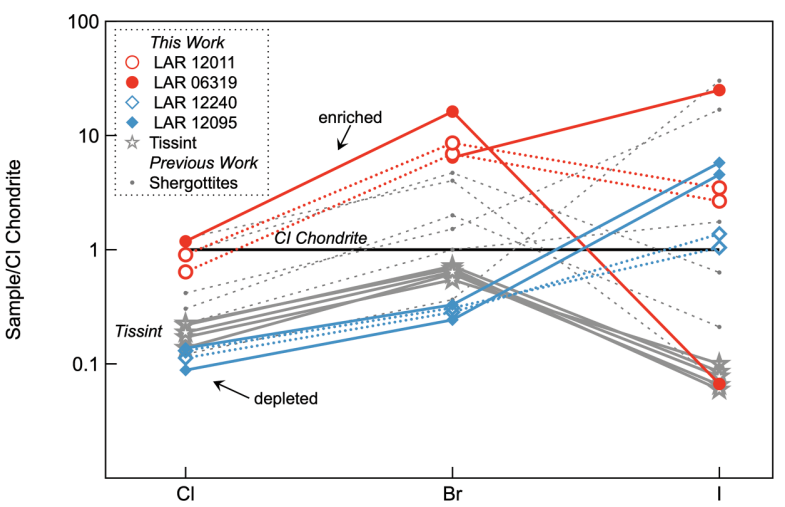

FIGURE 9. CI-chondrite normalized halogen abundances for shergottite samples measured in this study. CI chondrite data (black line) is from Clay et al. (2017) and shergottite reference lines (gray dashed lines) are from Dreibus and Wänke (1987). (Color online.)

slowly (Welsch et al. 2014; Watson et al. 2015). Our P mapping in olivine are somewhat ambiguous, in that one of the crystals in Figure 1d may exhibit resorption surfaces, but the other does not. However, an equally interesting microstructural feature of our P mapping is the excellent preservation of primary dendritic crystallites in the cores of some crystals. The exposure of such dendrites is generally dependent on the 2D intersection of the olivine crystal in question, so they might be much more widespread than presently observed in the Tissint meteorite. The presence of these dendrites, particularly when coupled with the observation that the distribution of $\mathrm{Cr}$ (which diffuses an order of magnitude faster than $\mathrm{P}$ in olivine) preserves the same structure, has implications for the growth rate and cooling history of the Tissint macrocrysts. In essence, we suggest that it is very unlikely that the olivine crystals in Tissint formed in a cumulate that remained at high temperature for any protracted (several months) period of time (Welsch et al. 2014; Watson et al. 2015). For example, at $850{ }^{\circ} \mathrm{C}$, using the diffusion parameters provided in Watson et al. (2015) for $P$ in olivine, it would take only 100 days for $P$ to diffusively equilibrate over a length-scale of $5 \mu \mathrm{m}$, effectively erasing the evidence of fine-scale P-zoning. Furthermore, the preservation of $\mathrm{Cr}$-zoning in Tissint olivine (Supplemental ${ }^{1}$ Fig. S4), a faster diffuser than P, requires an even faster cooling regime. This suggests that even though localized evidence of resorption on olivine surfaces may exist, the Tissint olivine macrocrysts are more likely to be phenocrysts rather than a reentrained cumulate and are in, or close to, chemical equilibrium with their host groundmass. Assuming that the same can be said for the remainder of the crystal cargo in the Tissint meteorite, in particular the dominant halogen carrier phase(s) such as apatite, then the bulk rock (groundmass plus crystals) may be considered as a closed system and thus represents a good proxy for extrapolating backward to its mantle source composition.

Depleted shergottite source composition and bulk silicate Mars. Based on the previous discussion, we use halogen abundances in the Tissint meteorite to estimate the composition of the depleted shergottite mantle source. Furthermore, in conjunction with reported halogen compositions of the martian crust (Gellert et al. 2004, 2006; Keller et al. 2006; Taylor et al. 
2010), an estimate of the halogen composition of bulk silicate Mars (BSM) can be calculated. The mass of Mars is $6.2 \times 10^{23} \mathrm{~kg}$ of which the martian crust and mantle are modeled to be $\sim 5.8$ and $94.2 \%$, respectively (e.g., Goettel 1981). Using the average halogen composition of Tissint yields a depleted shergottite source composition of $1.2 \mathrm{ppm} \mathrm{Cl}, 7.0 \mathrm{ppb} \mathrm{Br}$, and $0.2 \mathrm{ppb} \mathrm{I}$, by assuming the fraction of the martian crust is approximately representative of the degree of partial melt (Taylor et al. 2010). Combined with estimates of $\mathrm{Cl}$ in the martian crust of $350 \mathrm{ppm}$ (Taylor et al. 2010), and conservatively assuming the proportions in the martian crust are approximately chondritic, a BSM halogen composition of $\sim 22 \mathrm{ppm} \mathrm{Cl}, \sim 74 \mathrm{ppb} \mathrm{Br}$, and $\sim 6 \mathrm{ppb} \mathrm{I}$ is calculated. While the $\mathrm{Cl}$ is similar to estimates from Taylor et al. (2010) of $32 \pm 9 \mathrm{ppm}$, our Br estimate is lower by a factor of $\sim 2.5(191 \pm 58 \mathrm{ppb})$. A comparison with estimates of bulk silicate Earth $(25 \pm 9 \mathrm{ppm} \mathrm{Cl}, 74 \pm 26 \mathrm{ppb} \mathrm{Br}$, and $14 \pm 11 \mathrm{ppb} \mathrm{I}$; McDonough and Sun 1995; Clay et al. 2017) suggests that the silicate portions of Mars and Earth have broadly similar bulk halogen compositions. Previous work on the terrestrial halogen budget has shown that terrestrial heavy halogens could be accounted for by accretion, not precluding the later addition of halogens in a "late veneer" event (Clay et al. 2017). The similarity of BSE and BSM halogen budgets might therefore suggest a common carrier(s) or process(es) for halogen delivery to the terrestrial planets.

\section{IMPLICATIONS}

Our results suggest the enriched and depleted shergottite mantle sources have a distinct halogen geochemical signature. This is consistent with previous work suggesting heterogeneously distributed volatiles in the martian mantle (e.g., McCubbin et al. 2016). Given estimates that the enriched and depleted shergottite mantle sources were distinct as early as $\sim 4504 \mathrm{Ma}$ (e.g., Borg et al. 2016), depleted and enriched shergottite halogen source compositions were probably defined early on in Mars' history. The martian surface is known to be particularly $\mathrm{Cl}$ - and $\mathrm{Br}$-rich (e.g., Gellert et al. 2004, 2006; Taylor et al. 2010), largely due to the presence of salts and alteration assemblages on the surface. However, the source of this surficial enrichment is unclear. A halogen-poor depleted shergottite mantle source and a potential halogen-rich enriched mantle shergottite source might indicate that some volatiles were transferred from the mantle to crust early in Mars' history. Given the hydrophilic nature of the halogens, the role of aqueous fluids would likely have been important in the concentration and transportation of halogens to the early martian surface, a similar process to what is suggested for sequestration of halogens in the surface reservoirs on early Earth (Clay et al. 2017).

Another similar observation to Earth is that of the uncertainty surrounding the bulk I composition of both the martian crust and mantle. Measurements of the I composition of bulk and mineral phases in ancient crustal lithologies (e.g., as represented by meteorite NWA 7034 and grouped stones) would usefully improve our knowledge of the martian I budget. Finally, the early sequestration of halogens into the martian surface has significant implications for the habitability of Mars: while salts are generally thought to be important for life, an overabundance may have a detrimental effect on wider planetary habitability.

\section{ACKNOWLEDGMENTS}

We thank Christopher Griffin, who was funded by a Paneth Meteorite Trust summer internship (administrated by the Royal Astronomical Society), and University of Manchester student Alejandro Leiva who assisted in collecting EMPA and SEM data for this study. John Cowpe and Lydia Fawcett are thanked for assistance with irradiation organization and instrument support. We acknowledge editorial suggestions from Anita Cadoux and two constructive reviews by Lydia Hallis and Sami Mikhail, all of which improved an earlier version of the manuscript.

\section{FUNDING}

We acknowledge the NASAAntarctic Meteorite Working Group for providing shergottite samples: LAR 06319,64, LAR 12011,6, LAR 12095,8, and LAR 12240,6 (bulk) and LAR 06319,46, LAR 12011,22, LAR 12095,28, and LAR 12240,17 (thin sections). We acknowledge funding by EPSRC, award EP/M028097/1, which supports the JEOL JXA-8530F FEG-EPMA. This work was in parts supported by the European Research Council (ERC) FP7 "NOBLE" grant no. 267692 (C.J.B), Royal Society (grant RS/UF140190) and STFC (grant ST/R000751/1) (K.H.J., R.B.), and partially by the NCCR "Planet S", funded by the Swiss SNF (H.B.).

\section{REFERENCES CITED}

Aiuppa, A., Baker, D.R., and Webster, J.D. (2009) Halogens in volcanic systems. Chemical Geology, 263, 1-18.

Anders, E., and Grevesse, N. (1989) Abundances of the elements: Meteoritic and solar. Geochimica et Cosmochimica Acta, 53, 197-214.

Avice, G., Bekaert, D.V., Chennaoui Aoudjehane, H., and Marty, B. (2018) Noble gases and nitrogen in Tissint reveal the composition of the Mars atmosphere. Geochemical Perspective Letters, 6, 11-16.

Baird, A.K., Toulmin, P. III, Clark, B.C., Rose, H.J. Jr., Keil, K., Christian, R.P., and Gooding, J.L. (1976) Mineralogic and petrologic implications of Viking geochemical results from Mars: Interim results. Science, 194, 1288-1293.

Balta, J.B., Sanborn, M., McSween, H.Y., and Wadhwa, M. (2013) Magmatic history and parental melt composition of olivine-phyric shergottite LAR 06319: Importance of magmatic degassing and olivine antecrysts in Martian magmatism. Meteoritics and Planetary Sciences, 48, 1359-1382.

Balta, J. B., Tucker, K., Wadhwa, M., and McSween, H.Y. (2015a) Petrology and geochemistry of new Antarctic shergottites: LAR 12011, LAR 12095, and LAR 12240. 46th Lunar and Planetary Science Conference, Abstract 2294.

Balta, J.B., Sanborn, M.E., Udry, A., Wadhwa, M., and McSween, H.Y. (2015b) Petrology and trace element geochemistry of Tissint, the newest shergottite fall. Meteoritics and Planetary Sciences, 50, 63-85.

Basu Sarbadhikari, A., Day, J.M.D., Liu, Y., Rumble, D. III, and Taylor, L.A. (2009) Petrogenesis of olivine-phyric shergottite Larkman Nunatak 06319: Implications for enriched components in martian basalts. Geochimica et Cosmochimica Acta, 73, 2190-2214.

Basu Sarbadhikari, A., Goodrich, C.A., Liu, Y., Day, J.M.D., and Taylor, L.A. (2011) Evidence for heterogeneous enriched shergottite mantle sources in Mars from olivine-hosted melt inclusions in Larkman Nunatak 06319. Geochimica et Cosmochimica Acta, 75, 6803-6820.

Basu Sarbadhikari, A., Babu, E.V.S.S.K., Vijaya Kumar, T., and Chennaoui Aoudjehane, H. (2016) Martian meteorite Tissint records unique petrogenesis among the depleted shergottites. Meteoritics and Planetary Science, 51, 1588-1610.

Bellucci, J.J., Whitehouse, M.J., John, T., Nemchin, A.A., Snape, J.F., Bland, P.A., and Benedix, G.K. (2017) Halogen and $\mathrm{Cl}$ isotopic systematics in Martian phosphates: Implications for the $\mathrm{Cl}$ cycle and surface halogen reservoirs on Mars. Earth and Planetary Science Letters, 458, 192-202.

Bogard, D., Garrison, D., and Park, J. (2010) Chlorine abundances in Martian meteorites. 41st Lunar and Planetary Science Conference. Abstract 1074.

Böhlke, J.K., and Irwin, J.J. (1992) Laser microprobe analyses of noble gas isotopes and halogens in fluid inclusions: Analyses of microstandards and synthetic inclusions in quartz. Geochimica et Cosmochimica Acta, 56, 187-201.

Borg, L.E., and Draper, D.S. (2003) A petrogenetic model for the origin and compositional variation of the Martian basaltic meteorites. Meteoritics and Planetary Science, 38, 1713-1731.

Borg, L.E., Brennecka, G.A., and Symes, S.J.K. (2016) Accretion timescale and impact history of Mars deduced from the isotopic systematics of martian meteorites. Geochimica et Cosmochimica Acta, 175, 150-167.

Brandon, A.D., Puchtel, I.S., Walker, R.J., Day, J.M.D., Irving, A.J., and Taylor, L.A. (2012) Evolution of the Martian mantle inferred from the ${ }^{187} \mathrm{Re}^{187} \mathrm{Os}$ isotope and highly siderophile element abundance systematics of shergottite meteorites, Geochimica et Cosmochimica Acta, 76, 206-235.

Brandon, A.D., Ferdous, J., and Peslier, A.H. (2017) Evaluating crustal contamination effects on the lithophile trace element budget of shergottites. Goldschmidt Conference, Paris 2017, Abstract 446.

Brazzle, R.H., Pravdivtseva, O.V., Meshik, A.P., and Hohenberg, C.M. (1999) Verification and interpretation of the I-Xe chronometer. Geochimica et Cosmochimica Acta, 63, 739-760.

Brennecka, G.A., Borg, L.E., and Wadhwa, M. (2014) Insights into the Martian 
mantle: The age and isotopics of the meteorite fall Tissint. Meteoritics and Planetary Science, 49, 412-418.

Bridges, J.C., and Warren, P.H. (2006) The SNC meteorites: basaltic igneous processes on Mars. Journal of the Geological Society, 163, 229-251.

Bridges, J.C., Catling, D.C., Saxton, J.M., Swindle, T.D., Lyon, I.C., and Grady, M.M. (2001) Alteration assemblages in Martian meteorites: Implications for near-surface processes. Space Science Reviews, 96, 365-392.

Burgess, R., Cartwright, J.A., and Filiberto, J. (2013) Halogen abundances of the Martian mantle. Mineralogical Magazine, 77, 793.

Busemann, H., Baur, H., and Wieler, R. (2000) Primordial noble gases in "phase Q" in carbonaceous and ordinary chondrites studied by closed-system stepped etching. Meteoritics and Planetary Science, 35, 949-973.

Cartwright, J.A., Ocker, K.D., Crowther, S.A., Burgess, R., and Gilmour, J.D. (2010) Terrestrial and Martian weathering signatures of xenon components in shergottite mineral separates. Meteoritics and Planetary Science, 45, 1359-1379.

Cartwright, J.A., Gilmour, J.D., and Burgess, R. (2013) Martian fluid and Martian weathering signatures identified in Nakhla, NWA 998 and MIL 03346 by halogen and noble gas analysis. Geochimica et Cosmochimica Acta, 105, 255-293.

Cartwright, J.A., Ott, U., Herrmann, S., and Agee, C.B. (2014) Modern atmospheric signatures in 4.4 Ga Martian meteorite NWA 7034. Earth and Planetary Science Letters, 400, 77-87.

Chennaoui Aoudjehane, H., Avice, G., Barrat, J.A., Boudouma, O., Chen, G., Duke, M.J.M., Franchi, I.A., Gattacceca, J., Grady, M.M., Greenwood, R.C., and others. (2012) Tissint Martian meteorite: a fresh look at the interior, surface, and atmosphere of Mars. Science, 338, 785-788.

Clay, P.L., Burgess, R., Busemann, H., Ruzié-Hamilton, L., Joachim, B., Day, J.M.D., and Ballentine, C.J. (2017) Halogens in chondritic meteorites and terrestrial accretion. Nature, 551, 614-618.

Crowther, S.A., and Gilmour, J.D. (2013) The Genesis solar xenon composition and its relationship to planetary xenon signatures. Geochimica et Cosmochimica Acta, 123, 17-34.

Day, J.M.D., Tait, K.T., McKay, D.S., Urdy, A., Moynier, F., Liu, Y., and Neal, C.R. (2018) Martian magmatism from plume metasomatized mantle. Nature Communications, 9, 4799 .

Dreibus, G., and Wänke, H. (1985) Mars, a volatile-rich planet. Meteoritics, 20, 367-381.

- (1987) Volatiles on Earth and Mars - A comparison. Icarus, 71, 225-240.

Dreibus, G., Spettel, B., Wlotzka, F., Schultz, L., Weber, H.W., Jochum, K.P., and Wänke, H. (1996) QUE 94201: An unusual Martian basalt. Meteoritics and Planetary Science, 31, A39-A40.

Dreibus, G., Spettel, B., Haubold, R., Jochum, K.P., Palme, H., Wolf, D., and Zipfel, J. (2000) Chemistry of a new shergottite: Sayh al Uhaymir 005. Meteoritics and Planetary Science, 35, A49-A49.

Dreibus G., Haubold R., Huisl W., and Spettel, B. (2003) Comparison of the chemistry of Yamato 980459 with $\mathrm{DaG} 476$ and $\mathrm{SaU}$ 005. International symposium, Evolution of Solar System materials: A new perspective from Antarctic meteorites, p. 19-20. National Institute of Polar Research, Tokyo.

Dreibus, G., Huisl, W., Spettel, B., and Haubold, R. (2006) Halogens in nakhlites: Studies of pre-terrestrial and terrestrial weathering. Lunar and Planetary Science Conference abstract 1180 .

Dunham, E.T., Balta, J.B., Wadhwa, M., Sharp, T.G., and McSween, H.Y. (2019) Petrology and geochemistry of olivine-phyric shergottites LAR 12095 and LAR 12240: Implications for their petrogenetic history on Mars. Meteoritics and Planetary Science, 54, 811-835.

Ferrat, M., Weiss, D.J., Spiro, B., and Large, D. (2012) The inorganic geochemistry of a peat deposit on the eastern Qinghai-Tibetan Plateau and insights into changing atmospheric circulation in central Asia during the Holocene. Geochimica et Cosmochimica Acta, 91, 7-31.

Filiberto, J., Chin, E., Day, J.M.D., Franchi, I.A., Greenwood, R.C., Gross, J., Penniston-Dorland, S.C., Schwenzer, S.P., and Treiman, A.H. (2012) Geochemistry of intermediate olivine-phyric shergottite Northwest Africa 6234, with similarities to basaltic shergottite Northwest Africa 480 and olivine-phyric shergottite Northwest Africa 2990. Meteoritics and Planetary Science, 47, 1256-1273.

Filiberto, J., Gross, J., and McCubbin, F.M. (2016a) Constraints on the water, chlorine, and fluorine content of the Martian mantle. Meteoritics and Planetary Science, 51, 2023-2035.

Filiberto, J., Baratoux, D., Beaty, D., Breuer, D., Farcy, B.J., Grott, M., Jones, J.H., Kiefer, W.S., Mane, P., McCubbin, F.M., and Schwenzer, S.P. (2016b) A review of volatiles in the Martian interior. Meteoritics and Planetary Science, $51,1935-1958$

Franz, H.B., Kim, S.-T., Farquhar, J., Day, J.D., Economos, R.C., McKeegan, K.D., Schmitt, A.K., Irving, A.J., Hoek, J., and Dottin, J. III (2014) Isotopic links between atmospheric chemistry and the deep sulphur cycle on Mars. Nature, 508, 364-368.

Fritz, J., Greshake, A., and Stöffler, D. (2005) Micro-Raman spectroscopy of plagioclase and maskelynite in Martian meteorites: Evidence of progressive shock metamorphism. Antarctic Meteorite Research, 18, 96-116.

Funk, R.C. (2016) Petrology and geochemistry of new paired martian meteorites LAR 12240 and LAR 12095, 130 pp. M.S. thesis, University of Houston, Texas.
Funk, R.C., Brandon, A.D., and Peslier, A. (2015) Petrology and geochemistry of new paired Martian meteorites 12095 and 12240. 46th Lunar and Planetary Science Conference, Abstract 2830.

Gellert, R., Rieder, R., Anderson, R.C., Brückner, J., Clark, B.C., Dreibus, G., Economou, T., Klingelhöfer, G., Lugmair, G.W., Ming, D.W., and others. (2004) Chemistry of rocks and soils in Gusev crater from the alpha particle X-ray spectrometer. Science, 305, 829-832.

Gellert, R., Rieder, R., Brückner, J., Clark, B.C., Dreibus, G., Klingelhöfer, G. Lugmair, G., Ming, D.W., Wänke, H., Yen, A., Zipfel, J., and Squyres, S.W. (2006) Alpha Particle X-Ray Spectrometer (APXS): Results from Gusev crater and calibration report. Journal of Geophysical Research, 111, E02S05.

Goettel, K.A. (1981) Density of the mantle of Mars. Geophysical Research Letters, $8,497-500$.

Goodrich, C.A. (2002) Olivine-phyric Martian basalts: A new type of shergottite. Meteoritics and Planetary Science, 37, B31-B34.

Gregory, T., Joy, K.H., Strekopytov, S., and Curran, N.M. (2017) Geochemistry and petrology of howardite Miller Range 11100: A lithologically diverse piece of the Vestan regolith. Meteoritics and Planetary Science, 52, 206-224.

Hallis, L.J., Kemppinen, L., Lee, M.R., and Taylor, L.A. (2017) The origin of alteration "orangettes" in Dhofar 019: Implications for the age and aqueous history of the shergottites. Meteoritics and Planetary Science, 52, 2695-2706.

Herd, C.D., Borg, L.E., Jones, J.H., and Papike, J.J. (2002) Oxygen fugacity and geochemical variations in the Martian basalts: Implications for Martian basalt petrogenesis and the oxidation state of the upper mantle of Mars. Geochimica et Cosmochimica Acta, 66, 2025-2036.

Herd, C.D.K., Walton, E.L., Agee, C.B., Muttik, N., Ziegler, K., Shearer, C.K., Bell, A.S., Santos, A.R., Burger, P.V., Simon, J.I., and others. (2017) The Northwest Africa 8159 martian meteorite: Expanding the martian sample suite to the early Amazonian. Geochimica et Cosmochimica Acta, 218, 1-26.

Holland, G., and Ballentine, C.J. (2006) Seawater subduction controls the heavy noble gas composition of the mantle. Nature, 441, 186-191.

Howarth, G.H., Liu, Y., Kohl, I., Pernet-Fisher, J.F., Wetterland, C., Chen, Y., Bodnar, R.J., Young, E.D., and Taylor, L.A. (2014) Heterogeneous olivine-phyric to pyroxene-phyric textures in paired shergottites LAR 12095 and LAR 12240. 46th Lunar and Planetary Science Conference. Abstract 1360.

Howarth, G.H., Liu, Y., Chen, Y., Pernet-Fisher, J., and Taylor, L.A. (2016) Postcrystallization metasomatism in shergottites: Evidence from the paired meteorites LAR 06319 and LAR 12011. Meteoritics and Planetary Science, 51, 2061-2072.

Irving, A.J., Kuehner, S.M., Tanaka, R., Herd, C.D.K., Chen, G., and Lapen, T.J. (2012) The Tissint depleted permafic olivine phyric shergottite; petrologic, elemental and isotopic characterization of a recent fall in Morocco. 43rd Lunar and Planetary Science Conference, Abstract 2510.

Karlsson, H.R., Clayton, R.N., Gibson, E.K. Jr., and Mayeda, T.K (1992) Water in SNC meteorites: Evidence for a Martian hydrosphere. Science, 255, 1409-1411.

Keller, J.M., Boynton, W.V., Karunatillake, S., Baker, V.R., Dohm, J.M., Evans, L.G., Finch, M.J., Hahn, B.C., Hamara, D.K., Janes, D.M., and others. (2006) Equatorial and midlatitude distribution of chlorine measured by Mars Odyssey GRS. Journal of Geophysical Research, 111, E03S08.

Kendrick, M.A. (2012) High precision $\mathrm{Cl}, \mathrm{Br}$ and I determinations in mineral standards using the noble gas method. Chemical Geology, 292-293, 116-126.

Kendrick, M.A., Kamenetsky, V., Phillips, D., and Honda, M. (2012) Halogen systematics $(\mathrm{Cl}, \mathrm{Br}, \mathrm{I})$ in Mid-Ocean Ridge Basalts: a Macquarie Island case study. Geochimica et Cosmochimica Acta, 81, 82-93.

Kendrick, M.A., Arculus, R., Burnard, P., and Honda, M. (2013) Quantifying brine assimilation by submarine magmas: Examples from the Galápagos Spreading Centre and Lau Basin. Geochimica et Cosmochimica Acta, 123, 150-165.

Kendrick, M.A., Jackson, M.G., Kent, A.J.R., Hauri, E.H., Wallace, P.J., and Woodhead, J. (2014) Contrasting behaviours of $\mathrm{CO}_{2}, \mathrm{~S}, \mathrm{H}_{2} \mathrm{O}$ and halogens $(\mathrm{F}, \mathrm{Cl}, \mathrm{Br}$, and I) in enriched-mantle melts from Pitcairn and Society seamounts. Chemical Geology, $370,69-81$.

Langenauer, M., and Krähenbühl, U. (1993) Depth-profiles and surface enrichment of the halogens in four Antarctic H5 chondrites and in two non-Antarctic chondrites. Meteoritics, 28, 98-104.

Lapen, T.J., Righter, M., Andreasen, R., Irving, A.J., Satkoski, A.M., Beard, B.L., Nishiizumi, K., Jull, A.J.T., and Caffee, M.W. (2017) Two billion years of magmatism recorded from a single mars meteorite ejection site. ScienceAdvances, 3, e1600922.

Leya, I., and Masarik, J. (2009) Cosmogenic nuclides in stony meteorites revisited. Meteoritics and Planetary Science, 44, 1061-1086.

Li, Y-H. (1991) Distribution patterns of the elements in the ocean: A synthesis. Geochimica et Cosmochimica Acta, 55, 3223-3240.

Liu, Y., Baziotis, I.P., Asimov, P.D., Bodnar, R.J., and Taylor, L.A. (2016) Mineral chemistry of the Tissint meteorite: Indications of two-stage crystallization in a closed system. Meteoritics \& Planetary Science, 51, 2293-2315.

Lodders, K. (1998) A survey of shergottite, nakhlite and chassigny meteorites whole-rock compositions. Meteoritics and Planetary Science, 33, 183-190.

McBride, K., McCoy, T., LaCroix, L., Welzenbach, L., and Sharp, Z. (2007) New meteorites: 2004-2006 collection. Antarctic Meteorite Newsletter, 30(2), 5-30. 
McBride, K., Harrington, R., Satterwhite, C., Corrigan, C., Singerling, S., Beck, A., Welzenbach, L., and McCoy, T. (2013) New meteorites: 2010 and 2012 collection. Antarctic Meteorite Newsletter, 36(2), 4-20.

McCubbin, F.M., Boyce, J.W., Srinivasan, P., Santos, A.R., Elardo, S.M., Filiberto, J., Steele, A., and Shearer, C.K. (2016) Heterogeneous distribution of $\mathrm{H}_{2} \mathrm{O}$ in the Martian interior: Implications for the abundance of $\mathrm{H}_{2} \mathrm{O}$ in depleted and enriched mantle sources. Meteoritics and Planetary Science, 51, 2036-2060.

McDonough, W.F., and Sun, S-s. (1995) The composition of the Earth. Chemical Geology, 120, 223-253.

Meyer, C. (2014) Mars Meteorite Compendium. Astromaterials Research and Exploration Science (ARES), Johnson Space Center, JSC no. 27672 Revision C.

Mikouchi, T., and Takenouchi, A. (2014) Mineralogy and petrology of LAR 12095 olivine-phyric shergottite: A possible launch pair from Mars with Dar al Gani 476 and Sayh Al Uhaymir 005. 45th Lunar and Planetary Science Conference, Abstract 1858 .

Milman-Barris, M., Beckett, J., Baker, M., Hofmann, A., Morgan, Z., Crowley, M., Vielzeuf, D., and Stolper, E. (2008) Zoning of phosphorus in igneous olivine. Contributions to Mineralogy and Petrology, 155, 739-765.

Mittlefehldt, D.W., Lindstrom, D.J., Lindstrom, M.M., and Martinez, R.R. (1999) An impact-melt origin for lithology A of Martian meteorite Elephant Moraine A79001. Meteoritics and Planetary Science, 34, 357-367.

Nagao, K., and Park, J. (2008) Noble gases and cosmic-ray exposure ages of two Martian Shergottites, RBT 04262 and LAR 06319 recovered in Antarctica. Meteoritics and Planetary Science, 43, A107.

Nyquist, L.E., Bogard, D.D., Shih, C-Y., Greshake, A., Stöffler, D., and Eugster, O. (2001) Ages and geologic history of martian meteorites. Chronology and Evolution of Mars, 96, 105-164.

Ocker, K.D., and Gilmour, J.D. (2004) Martian xenon components in Shergotty mineral separates: Locations, sources, and trapping mechanisms. Meteoritics and Planetary Science, 39, 1967-1981.

Orosei, R., Lauro, S.E., Pettinelli, E., Cicchetti, A., Coradini, M., Cosciotti, B., DiPaolo, F., Flamini, E., Mattei, E., Pajola, M., and others. (2018) Radar evidence of subglacial liquid water on Mars. Science, 361, 490-493.

Park, J., Bogard, D.D., Nyquist, L.E., Garrison, D.H., and Mikouchi, T. (2013) Ar-Ar ages and trapped Ar components in Martian shergottites RBT 04262 and LAR 06319. Geochimica et Cosmochimica Acta, 121, 546-570.

Peslier, A.H., Hnatyshin, D., Herd, C.D.K., Walton, E.L., Brandon, A., Lapen, T.J., and Shafer, J.T. (2010) Crystallization, melt inclusion, and redox history of a martian meteorite: olivine-phyric shergottite Larkman Nunatak 06319. Geochimica et Cosmochimica Acta, 74, 4543-4576.

Rampe, E.B., Cartwright, J.A., McCubbin, F.M., and Osterloo, M.M. (2018) The role of halogens during fluid and magmatic processes on Mars. In D.E. Harlov and L. Aranovich, Eds., The Role of Halogens in Terrestrial and Extraterrestrial Geochemical Processes, pp. 959-995. Springer Geochemistry.

Rao, M.N., Sutton, S.R., McKay, D.S., and Dreibus, G. (2005) Clues to Martian brines based on halogens in salts from nakhlites and MER samples. Journal of Geophysical Research, 110, E12S06.

Renne, P.R., Mundil, R., Balco, G., Min, K., and Ludwig, K.R. (2010) Joint determination of ${ }^{40} \mathrm{~K}$ decay constants and ${ }^{40} \mathrm{Ar}^{*} / 40 \mathrm{~K}$ for the Fish Canyon sanidine standard, and improved accuracy for ${ }^{40} \mathrm{Ar} /{ }^{39} \mathrm{Ar}$ geochronology. Geochimica et Cosmochimica Acta, 74, 5349-5367.

Riebe, M.E.I., Welten, K.C., Meier, M.M.M., Wieler, R., Bart, M.I.F., Ward, D., Laubenstein, M., Bischoff, A., Caffee, M.W., Nishiizumi, K., and Busemann, H. (2017) Cosmic-ray exposure ages of six chondritic Almahata Sitta fragments. Meteoritics and Planetary Science, 52, 2353-2374.

Righter, M., Andreasen, R., and Lapen, T.J. (2015) Lu-Hf and Sm-Nd systematics of martian meteorites Larkman Nuntak 12011 and $12095.46^{\text {th }}$ Lunar and Planetary Science Conference, Abstract 2889

Ruzié-Hamilton, L., Clay, P.L., Burgess, R., Joachim, B., Ballentine, C.J., and Turner, G. (2016) Determination of halogen abundances in terrestrial and extraterrestrial samples by the analysis of noble gases produced by neutron irradiation. Chemical Geology, 437, 77-87.

Saal, A.E., Hauri, E.H., Langmuir, C.H., and Perfit, M.R. (2002) Vapour undersaturation in primitive mid-ocean-ridge basalt and the volatile content of Earth's upper mantle. Nature, $419,451-455$.

Schmidt, M.E., Farrand, W.H., Johnson, J.R., Schröder, C., Hurowitz, J.A., McCoy, T.J., Ruff, S.W., Arvidson, R.E., Des Marais, D.J., Lewis, K.W., Ming, D.W., Squyres, S.W., and de Souza, P.A. (2009) Spectral, mineralogical, and geochemical variations across Home Plate, Gusev Crater, Mars indicate high and low temperature alteration. Earth and Planetary Science Letters, 281, 258-266.
Schmidt, M.E., Campbell, J.L., Gellert, R., Perrett, G.M., Treiman, A.H., Blaney, D.L., Olilla, A., Calef, F.J. III, Edgar, L., Elliott, B.E., and others. (2014) Geochemical diversity in first rocks examined by the Curiosity Rover in Gale Crater: Evidence for and significance of an alkali and volatile-rich igneous source. Journal of Geophysical Research: Planets, 119, 64-81, doi:10.1002/2013JE004481.

Shafer, J.T., Brandon, A.D., Lapen, T.J., Righter, M., Peslier, A.H., and Beard, B.L. (2010) Trace element systematics and ${ }^{147} \mathrm{Sm}-{ }^{143} \mathrm{Nd}$ and ${ }^{176} \mathrm{Lu}-{ }^{176} \mathrm{Hf}$ ages of Larkman Nunatak 06319: Closed-system fractional crystallization of an enriched shergottite magma. Geochimica et Cosmochimica Acta, 74, 7307-7328.

Shih, C-Y., Nyquist, L.A., and Reese, Y. (2009) Rb-Sr and Sm-Nd studies of olivinephyric Shergottites RBT 04262 and LAR 06319: Isotopic evidence for relationship to enriched basaltic shergottites. $40^{\text {th }}$ Lunar and Planetary Science Conference, Abstract 1360

Shirai, N., and Ebihara, M. (2004) Chemical characteristics of a Martian meteorite, Yamato 980459. Antarctic Meteorite Research, 17, 55-67.

Stamenković, V., Ward, L.M., Mischna, M., and Fischer, W.W. (2018) $\mathrm{O}_{2}$ solubility in Martian near-surface environments and implications for aerobic life. Nature Geoscience, 11, 905-909.

Steele, A., Benning, L.G., Wirth, R., Siljeström, S., Fries, M.D., Hauri, E., Conrad, P.G., Rogers, K., Eigenbrode, J., Schreiber, A., and others. (2018) Organic synthesis on Mars by electrochemical reduction of $\mathrm{CO}_{2}$. Science Advances, 4, eaat5118.

Strekopytov, S.V., and Dubinin, A.V. (1997) Determination of Zr, Hf, Mo, W and Th in standard reference samples of ocean sediments by inductively coupled plasma mass spectrometry. Journal of Analytical Chemistry, 52, 1171-1174.

Symes, S.J., Borg, L.E., Shearer, C.K., and Irving, A.J. (2008) The age of the Martian meteorite Northwest Africa 1195 and the differentiation history of the shergottites. Geochimica et Cosmochimica Acta, 72, 1696-1710.

Takenouchi,A., Mikouchi, T., and Yamaguchi,A. (2018) Shock veins and brown olivine in Martian meteorites: Implications for their shock pressure-temperature histories. Meteoritics and Planetary Science, 53, 2259-2284.

Taylor, G.J., Boynton, W.V., McLennan, S.M., and Martel, L.M.V. (2010) K and Cl concentrations on the Martian surface determined by the Mars Odyssey Gamma Ray Spectrometer: Implications for bulk halogen abundances in Mars. Geophysical Research Letters, 37, L12204.

Usui, T., McSween, H.Y., and Floss, C. (2008) Petrogenesis of olivine-phyric shergottite Yamato 980459, revisited. Geochimica et Cosmochimica Acta, 72, 1711-1730.

Wänke, H., and Dreibus, G. (1994) Chemistry and accretion history of Mars. Philosophical Transactions of the Royal Society Series A, 349, 285-293.

Watson, E.B., Cherniak, D.J., and Holycross, M.E. (2015) Diffusion of phosphorus in olivine and molten basalt. American Mineralogist, 100, 2053-2065.

Welsch, B., Hammer, J., and Hellebrand, E. (2014) Phosphorus zoning reveals dendritic architecture of olivine. Geology, 42, 867-870.

Wieler, R. (2002) Cosmic-ray-produced noble gases in meteorites. Reviews in Mineralogy and Geochemistry, 47, 125-170.

Wieler, R., Huber, L., Busemann, H., Seiler, S., Leya, I., Maden, C., Masarik, J., Meier, M.M.M., Nagao, K., Trappitsch, R., and Irving, A.J. (2016) Noble gases in 18 Martian meteorites and angrite Northwest Africa 7812-Exposure ages, trapped gases, and a re-evaluation of the evidence for solar cosmic ray-produced neon in shergottites and other achondrites. Meteoritics and Planetary Science, 51, 407-428.

Wiens, R.C., Becker, R.H., and Pepin, R.O. (1986) The case for a martian origin of the shergottites, II. Trapped and indigenous gas components in EETA 79001 glass. Earth and Planetary Science Letters, 77, 149-158.

Williams, J.T., Shearer, C.K., Sharp, Z.D., Burger, P.V., McCubbin, F.M., Santos, A.R., Agee, C.B., and McKeegan, K.D. (2016) The chlorine isotopic composition of Martian meteorites 1: Chlorine isotope composition of Martian mantle and crustal reservoirs and their interactions. Meteoritics and Planetary Science, 51, 2092-2110.

Zipfel, J., Scherer, P., Spettel, B., Dreibus, G., and Schultz, L. (2000) Petrology and chemistry of the new shergottite Dar al Gani 476. Meteoritics and Planetary Science, $35,95-106$.

MANUSCRIPT RECEIVED JULY 31, 2019

MANUSCRIPT ACCEPTED OCTOBER 31, 2019

MANUSCRIPT HANDLED BY ANITA CADOUX

\section{Endnote:}

${ }^{1}$ Deposit item AM-20-37237, Supplemental Figures and Tables. Deposit items are free to all readers and found on the MSA website, via the specific issue's Table of Contents (go to http://www.minsocam.org/MSA/AmMin/TOC/2020/Mar2020_data/ Mar2020 data.html) 